\title{
POLISH SETTLEMENT IN MANCHURIA (1898-1950) A BRIEF HISTORICAL SURVEY
}

The Far East ${ }^{1}$, especially Manchuria as well as various parts of Siberia, was for a century and a half the scene of endless peregrinations and long sojourns of political exiles from Poland, whom Russian tyranny drove into these wildernesses ${ }^{2}$, and many of whom made significant contributions to the scientific, economic and social development of that part of $\mathrm{Asia}^{3}$. In course of time numerous Poles - partly

Mariusz Borysiewicz, MA - doctoral candidate, Institute of History and Political Sciences, Faculty of Philologies and History, Pomeranian University in Słupsk; e-mail: mariuszbory@wp.pl

${ }^{1}$ The Far East is a geographical term, which commonly refers to East Asia, including Northeast Asia, and the Russian Far East, that is a part of North Asia, not to mention Southeast Asia. Moreover, South Asia is often included for economic and cultural reasons (W.H.D. AdAms, In the Far East: A Narrative of Exploration and Adventure in Cochin-China, Cambodia, Laos, and Siam, Edinburgh 1879, pp. 106-130). Nowadays, however, this expression can be described as archaic and Eurocentric. The phrase Far East came into use in European geopolitical discourse in the twelfth century, denoting the Far East as the most distant of the three eastern regions, beyond the Near East and the Middle East (O.P. Austin, Trading with the Far East, Yokohama 1920, pp. 6-8). Before the First World War, within European geopolitics the Near East referred to the relatively nearby lands of the Ottoman Empire, the Middle East indicated northwestern South Asia and Central Asia, while the Far East meant countries along the western Pacific Ocean and eastern Indian Ocean (Centralne Archiwum Wojskowe [CAW: Central Military Archives], Oddział II Sztabu Głównego (Generalnego) z lat 1921-1939 [OIISG: The Second Department of Polish General Staff, 1921-1939], file no. I.303.4.5515, General description of the Far East, 1931, pp. 2-3). Similarly, Chinese people in the nineteenth and early twentieth century called Western countries the Far West, which meant any land or region located further west than the Arab world (P.M. D'EliA, Fonti Ricciane: Documenti Originali Concernenti Matteo Ricci e la Storia delle Prime Relazioni tra l'Europa e la Cina (15791615), Roma 1942-1949, pp. 50-64). Traditionally, the Russian Far East is frequently considered an integral part of Siberia (T. Michell, Russian Pictures Drawn with Pen and Pencil, London 1889, pp. 177; J.W. Bookwalter, Siberia and Central Asia, London 1900, pp. 85).

2 E. FelińsKa, Revelations of Siberia. By a Banished Lady, London 1852, p. 159.

${ }^{3}$ A number of notable Polish scholars - mostly dealing with biology, geology, geography, ethnography, anthropology and archeology - studied Siberia, for instance Aleksander Czekanowski 
political exiles and partly voluntary emigrants, being gifted with a spirit of enterprise - formed a vibrant local community, building up large industrial undertakings and making great fortunes both in sparsely populated plains of Siberia and vast forests of Northeastern China ${ }^{4}$.

During the late nineteenth century and early twentieth century, geopolitical, political as well as economic considerations combined to induce the Tsarist government to pursue a policy of mass colonization of the Far East ${ }^{5}$. This process led to the appearance of numerous Slavic enclaves in Northeastern China from the late 1890 s onwards $^{6}$. As a consequence, northern Manchuria became the final major meeting point between European settlers and Asian inhabitants of the borderland encompassing Tsarist Russia as well as Imperial China. The European settlement in Manchuria ${ }^{7}$ was to leave profound imprints on the region's changing landscape for the next half-century ${ }^{8}$.

(1833-1876), Jan Czerski (1845-1892), Benedykt Dybowski (1833-1930), Wiktor Godlewski (1831-1900), Sergiusz Jastrzębski (1857-1931), Edward Piekarski (1858-1934), Bronisław Piłsudski (1866-1918), Wacław Sieroszewski (1858-1945), Mikołaj Witkowski (1843-1892) and others. When it comes to Manchuria, it is worth mentioning Kazimierz Grochowski (1873-1937), who supervised the geological survey on the Amur, on Sakhalin and in Inner Mongolia, and found petroleum in North China (Instytut Józefa Piłsudskiego w Ameryce [IJP: Józef Piłsudski Institute of America], Archiwum Józefa Piłsudskiego [AJP: Józef Piłsudski Acts, file no. 701/1/12, Facts from the life of Bronisław Piłsudski issued on the occasion of the 125th birthday anniversary, Vladivostok 1991, pp. 1-2; „Przegląd Krytyczny”, no. 8, 31 August 1877, p. 286; W. SieroszewsKi, Dwanaście lat w kraju Jakutów, Warszawa 1900, p. 2; „Kosmos”, vol. 25, 1900, p. 690; В.В. РАдлов, Отзыв к Э. К. Пекарский. Словарь якутского языка, „Живая Старина”, vol. 4, 1907, pp. 63-65; „Światowit”. Rocznik poświęcony archeologii i badaniom pierwotnej kultury polskiej i słowiańskiej, vol. 12-14, 1926, pp. 1-5; B. WiERZBIAŃski, Polacy w świecie, Londyn 1946, p. 158; A. KuCZyŃski, Syberyjskie szlaki, Wrocław 1972, p. 355; M. ILowIECKI, Dzieje nauki polskiej, Warszawa 1981, p. 164; J.J. Stephan, The Russian Far East. A History, Stanford 1994, p. 315).

4 B. WierzBiański, Polonia zagraniczna w latach 1939-1946, Londyn 1946, p. 118.

5 W. Kolarz, The Peoples of the Soviet Far East, New York 1954, pp. 12.

${ }^{6}$ In most cases, Europeans from the western fringes of the Russian Empire emigrated to its recently acquired possessions in the East. The first Russian colonists in the Far East had come chiefly from the overpopulated provinces of Kiev, Chernigov and Poltava. On the whole, the inhabitants of over forty-five European Russian provinces participated in the colonization after the hardships of a long and complicated journey had been alleviated by the opening of direct rail communication between Russia and the Far East around 1900 („Вестник Европы”, vol. 233, 1905, pp. 233-234; W. Kolarz, Russia and Her Colonies, London 1952, p. 126).

${ }^{7}$ Manchuria is a historical region of northeastern China. Currently, it consists of three Chinese provinces of Liaoning, Jilin as well as Heilongjiang. Usually, however, the northeastern portion of the Inner Mongolia is also included. Lying at the juncture of the Chinese, Japanese and Russian spheres of influence, Manchuria has been a cockpit of conflict since the late nineteenth century. At the beginning of the twentieth century the above term was unknown to the Chinese or to the Manchus as a geographical expression. Often it was spoken of as the Three Eastern Provinces, namely present-day Liaoning, Jilin and Heilongjiang (W. Doleżan, Mandżurya. Opis kraju i ludzi, Warszawa 1904, p. 7; H.A. Giles, China and the Manchus, Cambridge 1912, p. 8; B.L. Putnam Weale, The 
The reasons for a steady influx of European merchants, traders, entrepreneurs and occasionally vagabonds, including a substantial quota of Poles, into the borderline region between Tsarist Russia and Qing China, are many and varied. Contrary to popular imagination, Manchuria, although closely linked to China, was largely underdeveloped compared to the rest of the Empire. Notably, the economic and industrial development of Manchuria was instigated by the opening by the English of the port of Newchwang in $1858^{9}$, the Russian occupation of North Manchuria, the Sino-Japanese as well as Russo-Japanese wars ${ }^{10}$, the building of railways by Russia and Japan ${ }^{11}$, not to mention the founding of large-scale ports, such as Dairen and Harbin by Japanese militarists along with Russian railway tsars ${ }^{12}$.

Truth about China and Japan, New York 1919, p. 188). Manchuria enjoys extraordinary natural endowments, far beyond those of any other region adjacent to China proper (Gothaisches Jahrbuch Für Diplomatie, Verwaltung und Wirtschaft 1928, Gotha 1928, p. 459). The topography of Manchuria is defined by a broad central plain surrounded by a horseshoe of mountains that contain abundant and valuable timber, furs, medicinal plants, minerals as well as other natural resources. The soils of the plain, aeolian in the west and alluvial in the south and east, are fertile and relatively free of stone. The Manchurian summer is sufficiently warm and long to support a single crop as far north as the Amur River on the Russian border, while ample precipitation during the growing season ensures maximum plant response. Soy was Manchuria's principal crop (Y.T. MatsusaKa, The Making of Japanese Manchuria, 1904-1932, Cambridge 2001, p. 128). By 1908, the economic upswing caused by the explosive growth of soybean exports from northern Manchuria put an end to hard times for the entire region. Its opening to foreign residents on January 7, 1907 aided international trade. Manchuria's natural resources attracted an unending stream of land-hungry settlers (J.A. White, Diplomacy of the Russo-Japanese War, Princeton 1964, p. 29; S.N. Ogata, Defiance in Manchuria. The Making of Japanese Foreign Policy, 1931-1932, Westport 1984, p. 45).

${ }^{8}$ Archiwum Akt Nowych [AAN: Central Archives of Modern Records], Kolonia Polska w Mandżurii [KPM: Polish Colony in Manchuria], file no. 66, History of the Polish colony in Manchuria, edited by Kazimierz Krąkowski, p. 8.

9 A. Hosie, Manchuria: Its People, Resources and Recent History, Boston 1910, p. 191.

${ }^{10}$ Książnica Pomorska [KP: Pomeranian Library], Zbiory Specjalne [ZS: Special Collections], file no. 3399, Polish Economic Activity in the Far East, edited by Tadeusz Szukiewicz, Kraków 1949, p. 250.

${ }^{11}$ From the beginning of the Trans-Siberian railway's construction, taking place between 1891 and 1916, Sergei Witte (1849-1915), a highly influential Minister of Finance in Tsarist Russia, had underlined the decisive importance of colonization to the venture's eventual success. Similarly, the question of settlement was related to the building of the Trans-Manchurian railway, officially called the Chinese Eastern Railway. After the suppression of the Boxer uprising in Manchuria (1900), three years went into developing a liberal migration policy. The Finance Ministry's plan attracted a sizable groups of Poles, Armenians, Germans, Georgians, Ukrainians, Lithuanians, Latvians and Jews to Manchuria with promises of religious and ethnic tolerance. At that time, Chinese migration, both spontaneous and government-sponsored, began to fill in the Manchurian vacuum as well (S.Y. WiTTE, The Memoirs of Count Witte, translated by A. Yarmolinsky, Garden City 1921, pp. 86-89; D. WolfF, To the Harbin Station: The Liberal Alternative in Russian Manchuria, 1898-1914, Stanford 1999, pp. 78-79).

12 T. Hoshiro, Economic History of Manchuria, Seoul 1921, p. 5. 
The Russian territorial and cultural expansion across Manchuria was not unique. At that time, Western powers, especially Great Britain, were interested not only in importing merchandise from China but also in the possibility of opening the Chinese market to their own commerce ${ }^{13}$. In the eighteenth century, apart from the rise in importance and reserves of the East India Company in India, the United Kingdom also played a prominent role in trade with China ${ }^{14}$. However, increasing imports of Chinese goods demanded considerable financial outlays. In order to balance the deficit in trade, the Company introduced opium to China, in spite of the 1833 imperial decree that prohibited opium trade ${ }^{15}$. Aware of its own solid political and trade position, both in Europe and inside Asia, as well as of China's political and military weakness, the British did not hesitate to rely on arms so as to force the Qing dynasty into granting them favorable terms of commerce and political privileges ${ }^{16}$.

In reply to the destruction of opium stocks, on 13th June 1842, the British forces occupied Shanghai, crossed the Yangzi and started preparations for the attack on Nanjing. On 19th June 1842 the Treaty of Nanking, the first of three treaties of the so-called opium wars, that lasted intermittently until 1860, was ratified between the United Kingdom and the Qing China. The Nanking Treaty became the standard for other agreements ${ }^{17}$, such as the one signed with the United States on 3rd July 1844, the one signed with France on 24th October 1844, and the Treaty of Kulja signed with the Russian Empire on 25 th July $1851^{18}$. Additional countries were also interested in opening the Chinese market, namely Belgium, the Netherlands, Japan, Germany and Italy. For this reason, the Qing Imperial Maritime Customs witnessed a steady increase in imports of opium into China ${ }^{19}$. In order to understand the crisis surrounding China in the nineteenth century and early years of the

13 C.S. See, The Foreign Trade of China, New York 1919, pp. 182-185; H. Cordier, La Chine, Paris 1921, pp. 105-112.

${ }^{14}$ W.H. Brereton, The Truth about Opium, London 1882, pp. 10-11; D. Masson, The Collected Writing of Thomas de Quincey, vol. 14, London 1897, pp. 209-210; E.N. LA MotTe, The Opium Monopoly, New York 1920, pp. 1-5.

15 J.C. Melvill, Opium Trade: A Copy of all Papers and Despatches at the India House, on the Subject of Hostilities between the Chinese and British Subjects engaged in the Opium Trade, from 1830 to 1833, both Years Inclusive, London 1840, pp. 21-32; D. MATHESON, What is Opium Trade?, Edinburgh 1857, p. 6 .

16 The International Anti-Opium Association in Peking, The War Against Opium, Tientsin 1922, p. 11.

${ }^{17}$ E.H. PARKer, Chinese Account of the Opium War, Shanghai 1888, pp. 66-79.

18 J.M. Crawford, The Industries of Russia, St. Petersburg 1893, p. 206; W.F. MAYERs, Treaties between the Empire of China and foreign powers together with regulations for the conduct of foreign trade, conventions, agreements, regulations, etc., Shanghai 1906, pp. 97-99.

${ }^{19}$ L. Cioli, Histoire économique depuis l'antiquité jusqu'à nos jours, Paris 1938, pp. 143-145. 
twentieth century, it ought to be noted that about $79 \%$ of the pre-First World War China's territory was considered to be divided between different spheres of several foreign powers, including Russia $-42,3 \%$, Great Britain - 27,8\%, Japan $-4,3 \%$, France $-3,4 \%$ and Germany $-1,3 \%$. In this way, $79.1 \%$ of the land belonging to the then China was under control of foreign countries ${ }^{20}$.

Table 1: The amount of opium imported into particular regions of China and produced in China

\begin{tabular}{|l|c|c|c|c|c|c|}
\hline \multirow{2}{*}{\multicolumn{1}{|c|}{ Region }} & \multicolumn{6}{c|}{ Year } \\
\cline { 2 - 7 } & $\begin{array}{c}1863 \\
{\left[\text { Piculs }^{21} \text { ] }\right.}\end{array}$ & $\begin{array}{c}1867 \\
{[\text { Piculs] }}\end{array}$ & $\begin{array}{c}1879 \\
{[\text { Piculs] }}\end{array}$ & $\begin{array}{c}1888 \\
{[\text { Piculs] }}\end{array}$ & $\begin{array}{c}1897 \\
{[\text { Piculs] }}\end{array}$ & $\begin{array}{c}1905 \\
{[\text { Piculs }]}\end{array}$ \\
\hline Manchuria & no data given & 2,585 & 2,453 & 113 & 28 & 25 \\
\hline Chihli & 3,708 & 7,898 & 5,181 & 1,555 & 918 & 225 \\
\hline Shantung & 873 & 2,735 & 3,536 & 318 & 320 & 440 \\
\hline Hunan & 1,412 & 4,242 & 3,294 & 1,163 & 519 & 2240 \\
\hline Hupeh & 1,412 & 4,242 & 3,294 & 1,163 & 519 & 322 \\
\hline Kiangsi & 1,993 & 2,202 & 2,153 & 3,077 & 2,483 & 1,715 \\
\hline Anhwei & 22,389 & 16,788 & 3,141 & 3,400 & 1,557 & 1,626 \\
\hline Kiangsu & 22,389 & 16,788 & 28,199 & 22,182 & 17,676 & 18,077 \\
\hline Chekiang & 2,679 & 5,047 & 7,728 & 6,274 & 4,873 & 4,041 \\
\hline Fukien & 9,821 & 9,238 & 8,903 & 13,039 & 7,877 & 6,600 \\
\hline Formosa & no data given & 2,586 & 5,552 & 4,646 & $\begin{array}{c}\text { no data } \\
\text { given }\end{array}$ & $\begin{array}{c}\text { no data } \\
\text { given }\end{array}$ \\
\hline Kwangsi & 7,212 & 7,627 & 12,787 & 26,845 & 13,058 & 22 \\
\hline Kwangtung & 7,212 & 7,627 & 12,787 & 26,845 & 13,058 & 18,587 \\
\hline Other channels ${ }^{22}$ & 20,000 & 20,000 & 20,000 & 5,000 & 5,000 & 5,000 \\
\hline Home grown & 70,087 & 80,948 & 102,927 & 87,612 & 54,309 & 56,920 \\
\hline Total imported & 50,087 & 60,948 & 82,927 & 82,612 & 49,309 & 51,920 \\
\hline
\end{tabular}

Source: The International Anti-Opium Association in Peking, The War Against Opium, Tientsin 1922, p. 15.

20 T.T. Han, De Industrialisatie van China, Gravenhage 1922, p. 51.

${ }^{21}$ A traditional unit of weight used in China, where one picul equaled 133 pounds, approximately 60 kilograms (C. BabBaGe, On the Economy of Machinery and Manufactures, London 1846, p. 202).

${ }^{22}$ For example, by junk, either legitimately, but not reporting to the Imperial Maritime Customs, or smuggled. 
As early as in the seventeenth century, Russian expeditions were cautiously pushing towards the Qing Empire, officially the Great Qing, by way of Siberia. Consequently, early in the next century, the Sea of Okhotsk was reached by Russian hunters. No sooner had the Amur River been navigated than Kamchatka was explored and a treaty was concluded with the rulers of China. In 1768 and the following years, an organized exploration of the eastern reaches of the whole of Imperial Russia was undertaken ${ }^{23}$. The climax of these processes of colonization was attained, just as in the case of California, when Russians reached the Pacific coast and founded the city of Vladivostok ${ }^{24}$. In order to secure the North China markets for Russian merchants and businessmen, Tsarist government was determined to wrest Mongolia and Manchuria from China. Fortunately for the Russians, both Mongolia and Manchuria ${ }^{25}$ were only sparsely populated, mostly by local tribes, and less important from the political point of view, whereas the Western invasion took place in the very heart of China ${ }^{26}$.

Until 1905, Russian Empire occupied a privileged position in Manchuria. Russians seized the opportunity to extend their influence in Northern China by creating a new railway infrastructure ${ }^{27}$, namely a semi-colonial Chinese Eastern Railway ${ }^{28}$ and a number of settlements along the railway's right-of-way zone ${ }^{29}$. The single-

23 „Boston Post”, April 27, 1903, p. 4; J. ScOtT-Keltie, O.J.R. Howarth, History of Geography, London 1913, p. 72.

${ }^{24}$ Manchuria. Place of Possibilities for Japan, „Boston Daily Globe”, March 11, 1905, p. 4; Extra Ships are Chartered for Run, „The Daily Colonist”, March 5, 1915, p. 10; Bureau of Foreign Commerce, Commercial Relations of the United States with Foreign Countries during the Year 1908, vol. 2, Washington 1909, p. 626.

${ }^{25}$ To a certain extent, this situation occurred as a consequence of Manchu's hold on the Northeast of China, which their emperors had attempted to maintain as a cultural reserve. Nevertheless, countermanding centuries of edicts restricting migration to Manchuria, Han Chinese homesteaders flooded the region. Between 1927 and 1929 alone, an estimated one million settlers arrived each year, surpassing the number of Europeans who landed annually in the United States at the peak of its immigration wave. At the same time, more Manchu lived south of the Great Wall than in their former homeland, and culturally they had assimilated with the Han Chinese they once ruled (J.J. STEPHAN, The Russian Far East, pp. 72-79; M. Meyer, In Manchuria: A Village Called Wasteland and the Transformation of Rural China, New York 2015, pp. 3-4).

${ }^{26}$ „London Standard”, January 4, 1904, p. 5; S.A. KoRfF, Russia in the Far East, Washington 1921, pp. 10-11.

27 „Gazeta Grudziądzka”, no. 126, January 30, 1904, p. 2; „Gazeta Grudziądzka”, no. 37, March 26, 1905, p. 4.

${ }^{28}$ KP, ZS, file no. 3399, Polish island in the Yellow Sea, edited by Tadeusz Szukiewicz, 28 November 1949, p. 2; Manchurian Trouble, „Boston Daily Globe”, April 24, 1903, p. 22.

${ }^{29}$ Harbin, the Wonderful New Russian City in Manchuria, „Galveston Daily News”, February 27, 1904, p. 8; D. Ben-CanaAn, F. Grüner, I. ProdöHL, Entangled Histories. The Transcultural Past of Northeast China, New York 2014, pp. 17-18. 
-track line was meant to provide a shortcut for the world's longest railroad, the Trans-Siberian Railway ${ }^{30}$, from near the Siberian city of Chita, across northern Inner Manchuria through Harbin to the Russian port of Vladivostok ${ }^{31}$. This route drastically reduced the travel distance required along the originally proposed main northern passage to Vladivostok, which lay completely on Russian soil but was not completed until a decade after the Manchurian bypass ${ }^{32}$.

The final contract, corresponding to the essential requirements of Russia, and enabling the construction of the Chinese Eastern Railway across Manchuria, was signed on 8 September $1896^{33}$. Russians were granted a construction concession throughout Northern Manchuria under the supervision of Chinese Vice Minister of Public Works Xu Jingcheng (1845-1900). Construction works on the Chinese Eastern Railway began in July 1897 along the line connecting Chita, Hailar, Harbin as well as Nikolsk-Ussuriysky, and accelerated drastically after Russia concluded a twenty-five year long lease of Liaodong from China in $1898^{34}$. Officially, traffic on the line started in November 1901. However, regular passenger transportation from St. Petersburg to Vladivostok across the Trans-Siberian railway did not commence until July $1903^{35}$.

In 1898, construction of a 880 kilometers (550 miles) long branch line, most of which later on formed the South Manchuria Railway, began at Harbin, leading southwards through Eastern Manchuria, along the Liaodong Peninsula, to the ice-free deep-water port at Port Arthur, which Russia was fortifying and developing into a first-class strategic naval base and marine coaling station for its Far East Fleet and Merchant Marine ${ }^{36}$. The whole railroad consisted of three branches, that is the western branch, now the Harbin-Manzhouli Railway, the eastern branch, now the Harbin-Suifenhe Railway, and the southern branch, currently part of the Beijing-Harbin Railway, which intersected in Harbin. Furthermore, the railway and the concession, known as the Chinese Eastern Railway Zone, were administered from Harbin, a city which was founded by a Polish engineer Adam Szydłowski

30 J. GieyszTor, Kolej Syberyjska, „Kraj”, no. 18, May 14, 1897, pp. 2-6.

${ }^{31}$ M. Moustafine, Secrets and Spies. The Harbin Files, London 2002, p. 10.

${ }^{32}$ H.K. Tong, Facts about the Chinese Eastern Railway Situation, Harbin 1929, p. 15.

33 Е.Д. Гримм, Сборник договоров и других документов по истории международных отношений на Дапьнем Востоке (1842-1925), Москва 1927, pp. 110-113.

34 F. Patrikeeff, H. Shukman, Railways and the Russo-Japanese War. Transporting War, New York 2007, p. 43.

35 E. KAJdAŃSKI, Korytarz. Burzliwe dzieje Kolei Wschodniochińskiej 1898-1998, Warszawa 2000, pp. $12-58$.

36 S. Urbansky, Kolonialer Wettstreit. Russland, China, Japan und die Ostchinesische Eisenbahn, Frankfurt am Main 2008, pp. 25-170. 
on 16th May $1898^{37}$. Interestingly, in November 1898 , the total length of railway concessions in the Chinese Empire exceeded 6,420 miles $(10,332 \mathrm{~km})$, and was divided between a number of foreign powers, such as Great Britain $-2,800$ miles $(4,506 \mathrm{~km})$, Russia - 1,530 miles $(2,462 \mathrm{~km})$, Germany - 720 miles (1159 $\mathrm{km})$, Belgium -650 miles $(1046 \mathrm{~km})$, France -420 miles $(676 \mathrm{~km})$, the United States -300 miles $(483 \mathrm{~km})^{38}$. For the most part, the Chinese Eastern Railway was carried out with Belgian and French money and therefore " $\$ 25,000,000$ was sunk in the enterprise" 39 .

Having defeated Russians in 1905, after their second major war ${ }^{40}$, the Japanese found themselves strongly in possession of Manchuria throughout the control over the South Manchurian Railway ${ }^{41}$. The Russo-Japanese war was brought to a conclusion by the Treaty of Portsmouth signed on 5th September $1905^{42}$. By the terms of this agreement, Russia recognized Japan's political, military and economic interests in Korea. Secondly, transferred to Japan its lease and rights in the Liaotung Peninsula, which included the port of Dairen and the naval base of Port Arthur. Thirdly, ceded to Japan the southern section of the Russian-built Chinese Eastern Railway in Manchuria, between Changchun and Port Arthur ${ }^{43}$.

37 AAN, KPM, file no. 66, History of the Polish colony in Manchuria, edited by Kazimierz Krąkowski, p. 7. After 8 March 1898, engineer Adam Szydłowski set out on a mission ordered by Stanisław Kierbedź. Accompanying him were two countrymen, that is technicians Raweński and Wysocki. The team also included railway technicians, workers and even a surgeon. People and 30 carts drawn by horses loaded with valuables, including silver worth 100,000 rubles, melted into 5-kilogram bars, were guarded by a half-sotnya of Kuban Cossacks under the command of a Pole, Rittmeister Pawlewski. The caravan forced its way through inaccessible areas, wild mountains and mighty rivers. The travel was obstructed by melting snow, changing their route during rapid torrents. They progressed slowly, only 10-15 versts a day (10-15 kilometers). Prompted by the upcoming arrival date of the team of builders of the Chinese Eastern Railway, engineer Szydłowski decided to spend 450 kilograms of silver on a Chinese distillery closed after an attack by robbers of the Honghuzi consisting of 30 buildings, called Sian Fan. On 13 May 1898, the Saint Innocent ship reached the bank of the Songhua and three days later another vessel by the name of Odessa, carrying employees of the Chinese Eastern Railway Company. In this way, the city of Harbin was founded (K. GrochowsKI, Polacy na Dalekim Wschodzie, Harbin 1928, pp. 12-14).

38 T.T. Han, De Industrialisatie, p. 73.

39 F.A. TAlвot, The Railway Conquest of the World, Philadelphia 1911, p. 299.

40 Prior to the victory in the war against Russia in 1904-1905, Imperial Japan fought against China in 1894-1895 for the purpose of banishing Chinese influence over Korea. The war ended with a severe defeat of the Chinese army. However, when confronted with the demand of Russia, France and Germany to return Liaotung to China, Japan had no choice but to succumb (Б.А. Романов, Очерки дипломатической истории русско-японской войны, Москва 1955, p. 17; S.N. ОGATA, Defiance in Manchuria, pp. 3-4).

41 „San Antonio Express”, September 20, 1931, p. 2.

42 А.Л. ГАЛЬПЕРИНА, Очерки новой истории Японии (1640-1917), Москва 1958, p. 410.

43 Б.А. Романов, Очерки дипломатической, р. 572. 
Finally, ceded in perpetuity full sovereignty in the half of the Island of Sakhalin south of the fiftieth degree of north latitude and all adjacent islands ${ }^{44}$. This pact, followed by Russo-Japanese agreements of 1907, including a Treaty of Commerce and Navigation, effectively divided Manchuria into two spheres of influence, leaving the larger, northern part to Russia and the southern part to Japan. The rapprochement between Russia and Japan was prompted by two main reasons, such as pressure of the Japanese on North Manchuria and Mongolia and pressure of the Chinese as well as other foreigners on Russian and Japanese interests in Manchuria ${ }^{45}$, especially Americans were keen on keeping Northern China open to foreign $\operatorname{trade}^{46}$. Russians, on the other hand, tried unsuccessfully to restrict the rights of foreigners to trade and commerce in Manchuria ${ }^{47}$.

Both Russia and Japan struggled with the policy of whether to annex Manchuria or leave it in present condition and simply pour more forces into that region. However, Manchuria was seized by Japan after the Mukden Incident and a pro-Japanese government was installed the following year, exactly on 18th February $1932^{48}$, with Puyi (1906-1967), the last Qing emperor, as the nominal regent and emperor ${ }^{49}$. Manchukuo's government was abolished in 1945 after the defeat of Imperial Japan at the end of the Second World War. The territories formally claimed by the puppet state were first seized in the Soviet invasion of Manchuria in August 1945 and then officially transferred to Chinese administration in the upcoming year ${ }^{50}$.

44 J.V.A. MacMurray, Treaties and Agreements with and Concerning China 1894-1919, vol. 1, Washington 1921, pp. 522-525; Ю.В. КлЮчникОВ, А. САБАКИН, Международная политика новейшего времени в договорах, нотах и декларащиях. Часть 1: От Франиузской революиии до империалистической войны, Москва 1925, pp. 321-325; Е.Д. Гримм, Сборник договоров, pp. 166-168.

45 В.Я. АвАРИн, Империализм в Манчжурии, том I: Этапы империалистической борьбы за Манчжурию, Москва 1934, p. 110.

46 „New York Times”, July 17, 1910, p. 40; W. Wilson, Selected Addresses and Public Papers, New York 1918, p. 248; Е.Д. Гримм, Сборник договоров, pp. 141-143; Г. Ефимов, Очерки по новой и новейшей истории Китая, Москва 1951, р. 112.

47 Three Powers to Forcibly Protest, „Boston Daily Globe”, April 25, 1903, p. 8; „New York Times", March 9, 1910, pp. 8-9.

${ }^{48}$ H. Hussey, Manchukuo in Relation to World Peace. Things Not Told in the Report to the Commission of Enquiry, Geneva 1932, p. 62.

49 A.G. PUYI, From emperor to citizen. The autobiography of Aisin-Gioro Pu Yi, vol. 2, Peking 1964, p. 253.

${ }^{50}$ W. SkóRA, Placówki MSZ Drugiej Rzeczypospolitej w Harbinie w latach 1920-1941 na tle dziejów Chin i Mandżurii (Mandżukuo). Szkic do problemu, in: Na szlakach dwóch światów. Studia ofiarowane Profesorowi Jerzemu Hauzińskiemu w 45-lecie pracy naukowej i dydaktycznej, ed. A. Teterycz-Puzio, Słupsk 2016, pp. 683-684. 
In 1935, Manchukuo bought the Chinese Eastern Railway from the Soviet Union ${ }^{51}$. With Japanese investment and rich natural resources, the area became an industrial powerhouse. Thus, Manchukuo had its own issued banknotes, postage stamps and banks ${ }^{52}$. On the other hand, European companies were consequently eliminated from the Manchurian market ${ }^{53}$. The worst moment for the Western entrepreneurs, including many Polish businessmen, occurred when the Japanese deprived them of timber and mining concessions in Northern Manchuria ${ }^{54}$.

During the period of Russian involvement in the region, quickly followed by Japanese expansion and domination ${ }^{55}$, Manchuria became one of the few really prosperous industrialized regions in the Far East as well as Northern China ${ }^{56}$. The Japanese were content with making Manchuria an immense reservoir of raw materials, including rich coking coal, copper and iron, for industries in Japan ${ }^{57}$. Russian policy, in contrast, created a situation in which Manchuria was a desirable destination for manufacturers and businessmen from Europe, North America and western reaches of the Russian Empire ${ }^{58}$. By then, the northeastern corner of present-day China was commonly described as Manchuria by the non-Chinese, from the fact that the area in question was the home of the Manchu tribesmen who established the Manchu or Qing Dynasty which ruled in China from 1644 to 1912. The Chinese, however, referred to this region as the "Three Eastern Provinces" ("Tung San Sheng"), because of its administrative division into the three provinces of Liaoning, formerly known as Fengtien, in the South, Kirin in the East and Heilungkiang in the North. The eastern border of Manchuria was marked by the Korean Peninsula ${ }^{59}$. West of Manchuria was Mongolia, the vast area which stret-

${ }^{51}$ CAW, OIISG, file no. I.303.4.3145, Special Economic Report, no. 2/35, May 9, 1935, p. 772; KP, ZS, file no. 3399, Polish Economic Activity in the Far East, edited by Tadeusz Szukiewicz, Kraków 1949, pp. 257-258.

${ }^{52}$ CAW, OIISG, file no. I.303.4.3145, Actual Economic Report, no. 1/35, April 13, 1935, p. 685-686.

53 AAN, Ministerstwo Spraw Zagranicznych [MSZ: Ministry of Foreign Affairs], file no. 5413, Export Association of Polish Ironworks, 1933, p. 3.

${ }^{54}$ CAW, OIISG, file no. I.303.4.2015, Consular Report, June 6, 1937, p. 7.

55 S.K. HornBeck, Contemporary Politics in the Far East, New York 1916, p. 210.

56 Y. Chang, The Economic Development and Prospects of Inner Mongolia (Chahar, Suiyuan, and Ningsia), Shanghai 1933, p. 55.

57 V.A. Yakнontoff, Eyes on Japan, New York: Coward-McCann 1936, p. 110; United States Strategic Bombing Survey, Coals and Metals in Japan's War Economy, Washington 1947, pp. 1-3.

58 „Laurel Daily Leader”, July 25, 1929, p. 4; C.W. Young, Japanese Jurisdiction in the South Manchuria Railway Areas, Baltimore 1931, pp. 33-40.

59 E. GrabowsKi, Rozwój zaludnienia w Polsce w zestawieniu z innemi krajami. Wedlug spisu z dnia 30-go września 1921 roku, Warszawa 1922, p. 20. 
ched north of the Chinese Wall and south of Siberia. This territory was formerly divided in common usage into "inner" and "outer" Mongolia ${ }^{60}$.

In 1930s, Manchuria was primarily an agricultural country. Thus, the arable land was estimated at about 32,647,230 hectares (approximately 82,992,000 acres), or more than $28 \%$ of the total area in 1936 . The soil and climate throughout the region were adapted to the growing of beans, millet, wheat, oats, tobacco and barley ${ }^{61}$. In Southern Manchuria corn was a valuable crop as well ${ }^{62}$. During 1934, the area under wheat was 3,393,656 acres ( 645,000 tons), millet $-5,880,699$ acres (2,280,000 tons), soy beans $-9,881,654$ acres $(3,841,000$ tons), kaoliang $6,566,322$ acres $(3,784,000$ tons). Extensive forests also abounded and their estimated extent was 138,452 square miles $\left(358,589 \mathrm{~km}^{2}\right)^{63}$. The soil of certain districts, especially in the vicinity of Mukden and Harbin, was suitable for beet flax growing, and the industry was slowly developing. The number of livestock in 1933 was $1,806,980$ cattle, 3,054,707 horses, 3,235,410 sheep and 7,964,490 pigs. Moreover, Manchuria was rich in minerals, the output of which in 1936 was as follows: coal - 7,108,282 tons, limestone $-477,350$ tons, iron ore 993,143 tons, magnesite $-55,386$ tons. In 1932 , the output of pig iron was 368,181 tons and of coke, 416,306 tons. Further, in $1932,1,412,554$ tons of oil shale were produced, the yield of crude oil being 70,631 tons $^{64}$.

Accurate statistics of population and area were more difficult in the Far East than in other parts of the world ${ }^{65}$. Even contemporary researchers found it difficult to specify the exact number of population in China or Manchuria ${ }^{66}$. The population of China had been estimated for many years at about 400,000,000. In 1904, however, William Woodville Rockhill (1854-1914), American Minister to China, after a careful inquiry, came to the conclusion that the former estimates of $400,000,000$ were excessive and, in fact, the total population of China, including

${ }^{60}$ E. Stanford, Atlas of the Chinese Empire Containing Separate Maps of the Eighteen Provinces of China Proper and the Four Great Dependencies, London 1908, p. 22.

${ }^{61}$ F.D. Cloud, Why America is so interested in Manchuria, „New York Times”, March 27, 1910, p. 43.

62 J. ScotT-Keltie, The Statesman's Year-Book, London 1905, p. 538.

63 In 1937, the forest was estimated at 88 million hectares and the timber resources at 3,700 million cubic meters. Similar data was presented in the first decades of the twentieth century and in the early 1940s. As a result, the timber industry, next to the mining industry, became one of the most profitable industrial sectors in Manchuria (J. Scott-Keltie, The Statesman's Year-Book, London 1908, p. 852; M. EpsteIn, The Statesman's Year-Book, London 1940, p. 779).

${ }_{64}$ M. Epstein, The Statesman's Year-Book, London 1936, p. 775.

${ }^{65}$ A. Grochowski, Jeszcze o Polonii Mandżurskiej, „Nasza Rodzina”, no. 11(482), November 1984, p. 32.

${ }^{66}$ CAW, OIISG, file no. I.303.4.3095, Emigration in the Far East, 1933, pp. 1-2. 
Manchuria, Chinese Turkestan, but excluding Mongolia and Tibet, was approximately $325,000,000$, while the population of Mongolia and Tibet probably did not exceed 5,000,000 ${ }^{67}$. The Chinese Government Gazette of February 27, 1911 stated the Chinese population at 321,000,000. Ten years later, the Chinese maritime customs authorities prepared estimates placing the total population of China at $439,000,000^{68}$, with $19,000,000$ for Manchuria alone ${ }^{69}$.

The earliest statistics exclusively for Manchuria (1882) estimated the total population of that region at $12,000,000$ people and its area at $362,310 \mathrm{mi}^{2}(938,379$ $\left.\mathrm{km}^{2}\right)^{70}$. Another investigation, conducted in 1905, estimated the area of Manchuria at $364,000 \mathrm{mi}^{2}\left(942,756 \mathrm{~km}^{2}\right)$, while the population at $13,000,000^{71}$. Similar survey of 1910 stated the total area of Manchuria at $390,000 \mathrm{mi}^{2}$ and its population at $18,000,000$ people $^{72}$. According to the study of 1933, Manchuria consisted of three provinces $^{73}$, namely Liaoning with an area of $71,489 \mathrm{mi}^{2}\left(185,156 \mathrm{~km}^{2}\right)$, population of 15,000,000 and capital in Mukden; Kirin with an area of 103,352 $\mathrm{mi}^{2}(267,680$ $\mathrm{km}^{2}$ ), population of 9,200,000 and capital in Kirin; Heilungchiang with area of $224,887 \mathrm{mi}^{2}\left(582,455 \mathrm{~km}^{2}\right)$, population of 5,200,000 and Tsitsihar for its capital ${ }^{74}$.

Manchuria offered various business opportunities and a huge potential market for foreign services and goods ${ }^{75}$, especially those related to Manchurian railways, such as the Chinese Eastern Railway as well as the South Manchurian Railway ${ }^{76}$. The railroad-driven advancement of a territory with a long history of conquering

${ }^{67}$ A.H. Smith, The Uplift of China, New York 1907, p. 2.

${ }^{68}$ Interestingly, statistics compiled by the Chinese Ministry of the Interior in 1935, estimated the total population of China at 485,508,838 and in 1943 at 457,835,475, including Manchuria in both cases. These significant differences in the two estimates, each by the same authority, indicate how difficult it was to attempt to measure with accuracy population of China (M. EpsteIn, The Statesman's Year-Book, London 1936, p. 759; M. EpsTEIN, The Statesman's Year-Book, London 1943, p. 770).

${ }^{69}$ O.P. Austin, Trading, p. 36.

70 J. Scott-Keltie, The Statesman's Year-Book, London 1885, p. 753.

71 J. Scott-Keltie, The Statesman's Year-Book, London 1905, p. 522.

72 F.D. Cloud, Why America, p. 44.

73 W. Pelc, Mandżurska Polonia, „Nasza Rodzina”, no. 2(473), February 1984, p. 30.

74 The most comprehensive survey of 1943, estimated the total area of Manchuria at 503,013 $\mathrm{mi}^{2}$ $\left(1,303,143 \mathrm{~km}^{2}\right)$ and its population at 43,233,954 people. Therefore, Manchuria was larger than the combined land areas of present-day France and Germany (M. EPsTeIn, The Statesman's Year-Book, London 1943, p. 782; F. De Mello Vianna, The International Geographic Encyclopedia and Atlas, London 1979, p. 450).

75 KP. ZS, file no. 3398, Letter of Tadeusz Szukiewicz to the editor of the "Rzeczpospolita" Daily in Łódź, Kraków, 16 July 1945 (lack of pagination).

${ }^{76}$ CAW, OIISG, file no. I.303.4.5438, Russian and European emigration in the Far East, 1929, p. 271. 
and being conquered by its nearest neighbors ${ }^{77}$ manifested itself in numerous factors describing the socio-economic situation at the time in question ${ }^{78}$. The following table illustrates statistical range of the development of Manchuria between 1908 and 1930 by presenting figures, which stand for numbers of persons and area of farmland captured in official registers for tax or statistical purposes and may suffer from significant underreporting. These figures are from various sources, mainly state census figures and survey results cited in secondary literature.

Table 2: Registered population and farmland in the twentieth-century Manchuria

\begin{tabular}{|c|c|c|}
\hline Year & Registered population (persons) & Registered farmland (acreage) \\
\hline 1908 & $17,055,000$ & $120,000,000$ \\
\hline 1910 & $17,942,000$ & no data available \\
\hline 1912 & $18,415,714$ & $123,000,000$ \\
\hline 1915 & $20,112,100$ & $164,000,000-183,000,000$ \\
\hline 1924 & $25,700,000$ & $206,000,000$ \\
\hline 1930 & $31,030,000$ & no data available \\
\hline
\end{tabular}

Source: C.M. IsETT, State, Peasant and Merchant in Qing Manchuria, 1644-1862, Stanford 2007, p. 309.

The partitions of Poland at the end of the eighteenth century and then revolutions in the nineteenth century resulted in Polish émigré communities both in Russia $^{79}$ and Siberia ${ }^{80}$.

77 Blessed with rich resources of timber, coal and iron, both Russia and Japan, eagerly followed by Western powers, made plans to acquire Manchuria. Nominally, the territory was part of China but that nation was weakened by numerous wars as well as rebellions, and lacked modern armed forces to effectively repel invaders. China's weakness invited foreign powers to enter Manchuria (CAW, OIISG, file no. I.303.4.4476, Communiqué concerning the Far East, 1927, p. 53; J. Livingston, J. MoOre, F. Oldfather, Imperial Japan, 1800-1945, New York 1973, p. 432).

78 C.K. Armstrong, The North Korean Revolution, 1945-1950, Ithaca 2003, p. 19.

${ }^{79}$ By the beginning of the twentieth century 600,000 Poles lived in the Russian Empire outside of the Polish provinces. In Saint Petersburg, for instance, they numbered about 60,000, in Odessa and Riga perhaps 24,000, with around 20,000 in Moscow (M. Ember, C.R. Ember, I. Skoggard, Encyclopedia of Diasporas. Immigrant and Refugee Cultures Around the World, New York 2005, p. 256). Further displacement took place as North American farms replaced Polish estates in the Russian partition as suppliers of imported grain to western Europe. The world crisis in grain prices hit Poland severely in the mid 1880s. In the 1890s a severe depression rocked the Russian-controlled 
In the late nineteenth century, many Poles migrated beyond Siberia to the Far East in pursuit of better economic conditions ${ }^{81}$. Polish settlers and explorers that were discriminated in Russian-occupied areas of the former Polish-Lithuanian Commonwealth ${ }^{82}$, looked for a better life and career in the construction and operation

Congress Kingdom, which stopped exporting wheat to the West. Poland instead supplied textile goods to Russia and cheap labor through emigration throughout the world (E.J. BERo, Emigracja polska w stosunku do ogólnej emigracji, Nowy Jork 1920, pp. 1-2; J.J. BuкowczYK, A History of the Polish Americans, New Brunswick 2008, pp. 11-12).

${ }^{80}$ The complete partition of the Polish-Lithuanian Commonwealth by Habsburg Austria, the Kingdom of Prussia and the Russian Empire in the years 1772, 1793 as well as 1795 brought about waves of compulsory expatriates to Siberia. Russian authorities exiled numerous Poles to Siberia, starting with the eighteenth century opponents of the Russian Empire's increasing influence in the Polish-Lithuanian Commonwealth, most notably the members of the Bar Confederation of 17681772. After Russian penal law changed in 1847, exile and penal labor became common penalties for participants in national uprisings within Russian Empire. This led to sending an increasing number of Poles to Siberia for forced labor, when they then became known as exiles. Many of them remained there, forming a Polish minority in Siberia. However, certain exiles managed to escape, for example, Rufin Piotrowski, who fled from the Omsk region to France in 1846 (R. Bremner, Excursion in the Interior of Russia, vol. 2, London 1839, pp. 104-108; R. Piotrowski, My Escape from Siberia, London 1863, pp. 285-309; P. Dotsenko, The Struggle for a Democracy in Siberia, 1917-1920. Eyewitness Account of a Contemporary, Stanford 1983, p. 131). The majority of Polish exiles came from the participants and supporters of the November Uprising of 1830-1831 and of the January Uprising of 1863-1864, as well as from the participants of the 1905-1907 Revolution in the Kingdom of Poland. Around the late nineteenth century a limited number of Polish voluntary settlers, including peasants, moved to Siberia, attracted by the economic development of the region („Polish Fortnightly Review”, vol. 25, December 1941, p. 7; D. HoERder, Cultures in Contact. World Migrations in the Second Millennium, Durham 2002, p. 341). Polish migrants and exiles, many of whom were forbidden to move away from the region even after having finished serving their sentence, created a vibrant community, which spread further into Manchuria. The last participant of the January Uprising living in Harbin, namely Gustaw Wilczyński, died in 1934 („Daleki Wschód”, no. 5, 1934, p. 14). Moreover, hundreds of Poles took part in the construction of Trans-Siberian Railway. About 20,000 Poles lived in Siberia around the 1860s. An unsuccessful uprising of Polish political exiles in Siberia broke out in 1866 (W.I. Thomas, F. Znaniecki, The Polish Peasant in Europe and America, vol. 1, New York 1927, p. 460; J.J. Lerski, P. WróBel, R.J. KozICKI, Historical Dictionary of Poland, 966-1945, Westport 1996, p. 538). First World War multiplied the number of Poles in Siberia and Russia as a whole. The largest group comprised Polish men conscripted into the Russian army. Poles were also conscripted into the armed forces of Austria-Hungary. If captured, the Russian authorities incarcerated them in prison camps or other settlements, often in Siberia and the Far East (A. KuczyŃski, Syberia. Czterysta lat polskiej diaspory, Wrocław 1998, p. 106; P. Gatrell, Homelands. War, Population and Statehood in Eastern Europe and Russia, 1918-1924, London 2004, p. 140).

${ }^{81}$ Great Britain Foreign Office, British Foreign Office. Russia Correspondence, 1781-1945, London 1975, p. 372.

82 IJP, AJP, file no. 701/1/174, „Robotnik”, February 1894, pp. 1-2; IJP, AJP, file no. 701/1/12, „Jeniec Polak”, no. 36, 6 June 1918, p. 30. 
of the Trans-Siberian Railway, not to mention its extension in Manchuria ${ }^{83}$. They found work building the Chinese Eastern Railway and remained behind to help operate the line. Therefore, contemporary history of Polish settlement in Manchuria is entangled with the Russian-built Chinese Eastern Railway ${ }^{84}$ that linked Siberia with Northeastern China ${ }^{85}$.

Unfortunately, the contribution of numerous Poles to the creation of the railway line and the city of Harbin remains largely unnoticed. In fact, a considerable contingent of Polish engineers, architects and builders ${ }^{86}$, presumably $30 \%$ of all the staff involved in the construction ${ }^{87}$, founded the building, administrative, political and economical center of that railway which later on developed into a multinational metropolis and stronghold of Polish diaspora in Manchuria ${ }^{88}$. The first mayor of Harbin was Eugeniusz Dynowski ${ }^{89}$, later a long-time deputy mayor of the city ${ }^{90}$. During the dynamic years involving construction works on the Chinese Eastern Railway, the number of Polish specialists, officials, physicians, clerks, railwaymen and skilled workers was gradually increasing ${ }^{91}$. Most of them were tempted by the prospect of high wages and a possibility to start a comfortable life in Manchuria ${ }^{92}$.

${ }^{83}$ M. BerżyŃSKI, W.S. Sworakowski, Pięć lat pracy dla Polonii zagranicznej, Warszawa 1934, p. 275.

${ }^{84}$ In the first years of its existence, the line was better known by the Russian acronym КВЖД, representing Китайско-Восточная железная дорога (С. ХАРьинский, Что такое Китайская Восточная ж.д. и куда идут её миллионы??, Санкт-Петербург 1908, pp. 8-11).

${ }^{85}$ CAW, OIISG, file no. I.303.4.2726, Political and military situation in the Far East, 1921-1922, pp. 5-6.

${ }^{86}$ Г.В. Мелихов, Маньчжурия далекая и близкая, Москва 1991, pp. 76-80.

87 A. Winiarz, Gtówne kierunki i formy aktywności Polaków w Mandżurii w latach 1897-1949, in: Polskie ślady na Dalekim Wschodzie. Polacy w Harbinie, ed. A. Furier, Szczecin 2008, p. 28.

${ }^{88}$ E. KAJDAŃsKi, Fort Grochowski, Olsztyn 1982, pp. 184-186; M. CABANOwsKi, Tajemnice Mandżurii. Polacy w Harbinie, Warszawa 1993, p. 11; K.Y. Deog, Kolonia polska w Mandżurii, Kraków 2001, p. 46; M. KaŁuski, Polacy w Chinach, Warszawa 2001, pp. 60-62; H. KuromiYA, A. Peploński, Między Warszawa a Tokio. Polsko-japońska wspótpraca wywiadowcza 1904-1944, Toruń 2009, p. 315.

${ }^{89}$ Initially, Harbin's town council was dominated by Poles and Germans. The magistrate adopted a key plan for the construction of Harbin, which was developed by Polish engineer, Konstanty Jokisz, in the closing months of 1898 (K. Grochowski, Polacy, p. 55; „Biuletyn Polskiej Izby Handlowej w Harbinie”, no. 5, 1932, p. 3; „Listy Harbińskie”, no. 5, 1932, p. 2; E. KAJDAŃski, Polacy na Dalekim Wschodzie. Inżynier Kazimierz Grochowski, Czyngis-chan i złoto barona Ungerna, Warszawa 2014, p. 30).

${ }^{90}$ M. Kaluski, Polacy w Chinach, pp. 63-64.

${ }^{91}$ KP, ZS, file no. 3399, Polish Economic Activity in the Far East, edited by Tadeusz Szukiewicz, Kraków 1949, p. 250; „Pamiętnik Charbiński”, vol. 1, 1923, pp. 23-24; „Listy Harbińskie”, no. 5, 1932, p. 2; „Biuletyn Polskiej Izby Handlowej w Harbinie”, no. 5, 1932, p. 3.

${ }_{92}$ KP, ZS, file no. 3390, Memories from the years of youth in Harbin (1921-1945), edited by Emilia Czajewska, Szczecin 1985, pp. 1-2. 
The whole venture, of strategic importance for Russian Empire ${ }^{93}$, was overseen by the Main Board of the Chinese Eastern Railway Company. The board consisted of six members and was elected by the Tsarist government on 27th December 1896 in Saint Petersburg. Curiously, between 1896 and 1903, position of the vice president within this institution was held by a Pole, namely Stanisław Kierbedź, who was responsible for the successful development of the project ${ }^{94}$. Consequently, many Polish engineers, railway workers and specialists, whom Kierbedź knew from the time of works on construction of the Trans-Siberian Railway, found employment in managerial positions both in St. Petersburg as well as Vladivostok, and especially in Manchuria. At that time, many other Poles, engaged in the operation of the Chinese Eastern Railway, occupied equally exposed posts within the ranks of the company. For example, Zenobiusz Aleksander Rugiewicz functioned as a Director of the Main Board in St. Petersburg since $1905^{95}$. Accordingly, Teofil Hirszman, Stefan Offenberg, Karol Weber, Mikołaj Kazi-Girej and Aleksander Łętowski were among the most notable Polish engineers and experts accountable for the expansion of the projected wide-gauge railway line around Harbin ${ }^{96}$.

The list of Polish technologists and skilled workforce involved by the Tsarist government in the construction of the railway line and Harbin's infrastructure was considerably longer ${ }^{97}$. For this reason, amid the most prominent figures were engineer Zbydniowski and Stanisław Nernhejm, directly responsible for supervision over the construction of municipal water supply systems, sewerage system and tramway lines ${ }^{98}$. Over the years, Poles occupied significant positions related to economy, banking, medicine, administration and the judicial system within the local structures of the Russian authorities in railway's right-of-way zone ${ }^{99}$.

93 G. Krahmer, Syberya i znaczenie wielkiej kolei syberyjskiej, Warszawa 1898, p. 115.

94 „Inżynier Kolejowy”, no. 8-9, 1926, p. 239; E. KAJDAŃSKI, Dlugi cień wielkiego muru. Jak Polacy odkrywali Chiny, Warszawa 2005, pp. 248-252; E. KAJDAŃsKI, Wspomnienia z mojej Atlantydy, Kraków 2013, p. 12.

95 „Listy Harbińskie”, no. 5, 1932, p. 2.

96 M. JANIK, Dzieje Polaków na Syberii, Kraków 1928, p. 35; K. Symonolewicz, Miraże Mandżurskie, Warszawa 1932, pp. 181-182.

97 Others were employed as physicians, engineers, bankers and lawyers. Unlike other Polish diaspora communities around the world, encompassing migrant workers and peasants, this group largely comprised wealthy and educated individuals (KP, ZS, file no. 3390, Memories from the years of youth in Harbin (1921-1945), edited by Emilia Czajewska, Szczecin 1985, p. 5; Archiwum Archidiecezjalne w Gnieźnie [AAG: Archdiocesan Archive of Gniezno], Archiwum Prymasa Polski [APP: Primate of Poland Acts], file no. 65, „Listy Polskie z Dalekiego Wschodu Azji”, January 22, 1928, pp. 57-64).

98 AAN, KPM, file no. 16, Polish Welfare Committee, (lack of date and pagination).

99 J. TokArski, Przez Syberię, Mandżurię i Japonię do brzegów Oceanu Spokojnego, Lwów 1911, p. 54; W. THEISs, Dzieci syberyjskie. Dzieje polskich dzieci repatriowanych z Syberii i Mandżurii w latach 1919-1923, Warszawa 1992, p. 28. 
Among the Polish designers who left their mark on Harbin's architecture were engineer Ignacy Cytowicz, who planned the city's main railway station, engineer Ignacy Nowakowski, designer of numerous Art Nouveau buildings, engineer Jan Obłomiejewski, Head of the Department of City Development and his deputy engineer Klemens Kmita ${ }^{100}$.

In addition to an endless stream of railway workers of Polish origin ${ }^{101}$, Harbin hosted many dedicated Polish military and civilian doctors. In 1907, Tadeusz Nowkuński became the chief doctor of the Central Railway Hospital which was one of the first institutions created in the city, next to the meteorological station and post office ${ }^{102}$. There were other notable doctors working in this hospital, who came from the territory of former Congress Poland, namely Józef Czacki, Marian Kozubowski and Wacław Łazowski. Moreover, a large number of Polish physicians, such as Jan Modrzewski ${ }^{103}$. Nevertheless, Polish community was extremely diversified, and therefore consisted mostly of builders of the railway line ${ }^{104}$, people looking for a better business environment, such as Kazimierz Grochowski and Władysław Kowalski ${ }^{105}$, the approximately 1,500 refugees from Kolchak's dispersed 5th Siberian Rifle Division ${ }^{106}$, 1920s immigrants, principally former workers of

100 E. KAJDAŃsKi, Wspomnienia, p. 15.

${ }^{101}$ S. Nernhejm, Polonia harbińska (zarys historyczny), ,Daleki Wschód”, no. 7(57), 1934, p. 1.

102 Е. ТАскина, Неизвестный Харбин, Москва 1994, р. 12.

103 KP, ZS, file no. 3398, Letter of Tadeusz Szukiewicz to the Polish-Chinese Society, Warszawa, June 30, 1930, pp. 199-200.

104 AAG, APP, file no. 4, Report of the Organizational Council of Poles from Abroad, Warszawa 1932, p. 49; KP, ZS, file no. 3399, Polish Economic Activity in the Far East, edited by Tadeusz Szukiewicz, Kraków 1949, p. 247; KP, ZS, file no. 3390, Memories from the years of youth in Harbin (1921-1945), edited by Emilia Czajewska, Szczecin 1985, p. 54.

${ }^{105}$ KP, ZS, file no. 3399, Polish island in the Yellow Sea, edited by Tadeusz Szukiewicz, 28 November 1949, p. 1.

${ }^{106}$ A detailed analysis of the armed effort of the unit would go beyond the scope of this paper. In short, the Polish 5th Siberian Rifle Division was formed on the Russian territory in 1919 during the First World War, but the unit was attached to the White Russian formations and fought mostly in the Russian Civil War. The core of the division was composed of POWs of the former Austro-Hungarian Army and local Poles (IJP, Adiutantura Generalna Naczelnego Wodza [AGNW: Adjutancy-Commander in Chief], file no. 701/2/105, Letter of the Polish War Committee, represented by Sylwester Żukowski, to the Polish Government, Harbin, April 5, 1919, p. 435). The latter were descendants of Poles forcibly resettled to Siberia after failed November Uprising, January Uprising and other struggles with Imperial Russia. After three expeditions against Bolshevik forces approaching Novo-Nikolaevsk, the 5th Division covered the evacuation of Allied forces along the Trans-Siberian Railway. On 22nd December 1919, at Taiga, the Polish Legion made a stand against the Red Army but suffered heavy losses. Continuing to cover the retreat of the Czech forces, Polish troops found themselves surrounded by Bolshevik forces. Most of the once 16,000 men strong division were taken as prisoners of war or died during forced labor in the mines. A group of about 1,500, led by Colonel Kazimierz Rumsza. managed to evade capture and reached Harbin on 21st February 1920 (IJP, AGNW, file no. 
the Warsaw-Vienna Railway ${ }^{107}$, who reached the region in pursuit of work, and political exiles or their descendants ${ }^{108}$. Besides soldiers of the Polish 5th Siberian Rifle Division, the Polish colony in Harbin also consisted of veterans of the Russo-Japanese conflict and former conscripts to the Chinese Eastern Railway Guard ${ }^{109}$. As mentioned earlier, Russian annexation of Northeastern Manchuria triggered Polish presence in this area. The first Polish settlers in Manchuria were soldiers from the failed November Uprising sent into exile to the borderland between Russia and China. Even before that those Poles who were convicted for their opposition against the Russian rule were often put in border garrisons ${ }^{110}$. After 1831, however, the influx of soldiers of Polish origin, including young recruits, was so large that in military detachments of the Amur region every second soldier was

Report of the High Commissioner of the Republic of Poland in Siberia on the situation in Siberia and the Far East, Harbin, April 8, 1920, p. 46; KP, ZS, file no. 3399, Polish Economic Activity in the Far East, edited by Tadeusz Szukiewicz, Kraków 1949, p. 263; H. BAGIŃsKi, Wojsko Polskie na Wschodzie 1914-1920, Warszawa 1921, pp. 536-598; L.E. VINING, Held by the Bolsheviks. The Diary of a British Officer in Russia, 1919-1920, London 1924, p. 215).

107 The Warsaw-Vienna Railway provided a railroad system that operated in Congress Poland, a part of the Russian Empire, from 1845 until 1912, when it was nationalized by the Russian government, with a compensation paid to the shareholders - mostly Belgians and Germans. The main component of its network was a line $327.6 \mathrm{~km}$ in length from Warsaw to the Granica station on the border with the Austro-Hungarian Empire. There the line reached the Austrian railway network, offering connections to Vienna. It was the first railway line built in Congress Poland and the second in the Russian Empire, after a short stretch of $27 \mathrm{~km}$ between Tsarskoye Selo and Saint Petersburg which opened in 1837. The line used the standard European gauge $(1,435 \mathrm{~mm})$, as opposed to all other railways in the Russian Empire which used the broad gauge $(1,524 \mathrm{~mm})$. Hence, the Warsaw-Vienna Railway formed a system physically separated from other Russian railways (И.Е. АндРЕЁвский, Энииклопедический словарь Брокгауза и Ефрона, m. 5a, Санкт-Петербург 1892, p. 565-567; Н.С. КонаРев, Железнодорожньй транспорт: Энциклопедия, Москва 1994, pp. 57-58).

108 AAN, KPM, file no. 6, Appeal to the Delegates of the Polish War Committee in Russia, Vladivostok, March 12, 1919, p. 12.

109 The Chinese Eastern Railway Guard Force was established by the Main Board of the Chinese Eastern Railway Company in 1897. Soon, however, the unit was transformed into the Trans-Amur Region of the Border Guard Corps in January 1901. The main objective of the guard was to defend the property and employees of the railway company along its right of way belt in Manchuria. After the conversion into the Trans-Amur Border Guard Corps, the force consisted of 25,000 men (KP, ZS, file no. 3399, Polish Economic Activity in the Far East, edited by Tadeusz Szukiewicz, Kraków 1949, p. 250; H. BAGIŃSKI, Wojsko Polskie, pp. 78-79; J. BiAŁYNIA-CHŁODECKI, Ćwierćwiecze kolonii polskiej w Charbinie na Dalekim Wschodzie, Lwów 1923, p. 5; „Daleki Wschód”, no. 7, 1934, p. 1). By then, the unit was under direct jurisdiction of Sergei Witte, Minister of Finance and Chairman of the Council of Ministers of the Russian Empire. Between 15 and 30 percent of all the officers within the Trans-Amur Region of the Border Guard Corps were of Polish origin (KP, ZS, file no. 3399, Polish island in the Yellow Sea, edited by Tadeusz Szukiewicz, 28 November 1949, p. 2).

110 A. Aleksandrowicz, Mandżuria, jej przeszłość, teraźniejszość, kraj i ludzie, Warszawa 1937, s. 107. 
Polish. They were used not only as armed forces, but also dealt with scientific research, administration and development of the Russian-occupied territories ${ }^{111}$. Among them Captain Jan Czerkawski was involved in the construction of almost all Russian posts on the Amur and therefore was made the first commanding officer of Vladivostok $^{112}$. Nevertheless, only voluntary arrivals contributed to the onset of noticeable cluster of Poles in Northeast Asia.

In 1903, the Polish community in Manchuria consisted of 7,000 people ${ }^{113}$, most of whom worked for the railway company. At the same time, Harbin occupied more than 20 square kilometers ${ }^{114}$. The number of Poles in Manchuria increased after the Russo-Japanese war, when tens of thousands of soldiers from the Kingdom of Poland were sent to fight in the Far East. At the end of hostilities, some of them settled in the hope of improved prospects. At its peak between 1917 and mid 1920s, the Polish enclave in Harbin numbered over 10,000 people ${ }^{115}$, who enjoyed a relatively peaceful environment on Chinese soil. For a time, many small towns and villages along the Chinese Eastern Railway's route additionally encapsulated from 6,000 to 10,000 Polish settlers in Northern Manchuria ${ }^{116}$. Beginning in 1924, the number of Polish citizens in Harbin dropped drastically. Former soldiers and prisoners of war had been repatriated to Poland ${ }^{117}$. However, Poles left Harbin

111 KP, ZS, file no. 3399, Polish Economic Activity in the Far East, edited by Tadeusz Szukiewicz, Kraków 1949, p. 250.

112 M. Kaluski, Polacy w rosyjskiej Mandżurii, „Studia Polonijne”, vol. 22, 2001, pp. 109-111.

113 AAN, MSZ, file no. 10389, Report on the Poles in the Far East, 1925, p. 5.

114 L. Victoir, V. Zatsepine, Harbin to Hanoi. The Colonial Built Environment in Asia, 18401940, Hong Kong 2013, p. 21.

115 В.А. Анучин, Географические очерки Маньчжурии, Москва 1948, р. 39; В.П. Петров, Город на Сунгари, Вашингтон 1984, pp. 8-10.

116 CAW, OIISG, file no. I.303.4.2725, Polish Colony in Siberia, 1921, p. 55.

117 The repatriation of Polish civilians took place as well. Numerous organizations sprang up throughout the Far East to provide for the needs of Polish individuals. Since 1918 Vladivostok had been the base of the Polish War Committee (PKW). Although the Committee was a military organ, one of its first initiatives was to claim liberation from Russian citizenship of all Poles in Siberia and the Far East, and the establishment of national freedom. Similar developments took place in other parts of Russian-occupied lands wherever Polish communities were located. During the First World War, Ignacy Sobieszczański, one of the most influential Poles living in Irkutsk, had formed the Committee for Assisting the Victims of the War and a Citizens' Committee, while similar organizations had sprung up elsewhere in Siberia. Later on, as foreigners found their lives in increased danger, the Polish Civic Organization (POS) was established. In collaboration with the PKW, POS established a Legitimacy Commission, which issued 'Polishness Certificates', that the Allies recognized during the years between 1918 and 1920. The First Congress of Poles in Siberia, which was held in Harbin on 18 March 1918, was the brainchild of these organizations, although it was convened under the aegis of the Polish Political Council of the Far East and Eastern Siberia. In October 1918 the Central Polish National Committee (PKN) was established in Harbin. Its members 
mainly due to declining labor market and the subsequent restrictions imposed on them by successive governments exercising control over the city ${ }^{118}$. Therefore, Polish population in Manchuria declined to approximately 5,000 settlers in the late $1920 \mathrm{~s}^{119}$. In 1930, the Polish community in the region comprised a total of only 2,000 or 3,000 pioneers ${ }^{120}$, and roughly half of them stayed in Harbin ${ }^{121}$. After Japan seized Southern Manchuria in 1931 and the outbreak of war in the Pacific, more Polish citizens decided to leave those areas. Between 1935 and 1949, the number of Polish residents of Harbin was steady, coming to approximately 1,500 persons ${ }^{122}$. Until 1958, most of the remaining Poles were gradually leaving Manchuria to settle in Poland, the United States or Australia ${ }^{123}$.

The main Polish settlement was located in the city of Harbin, which emerged as a product of the century-old rivalry between China, Russia and Japan for control of Manchuria. In the short course of approximately one hundred years, Harbin has been ruled by Russia, by an international coalition of Allied powers, by Chinese warlords, by Japan, by the Soviet Union and finally by the Chinese Communists, who established their control of the city in 1946. Probably no other Chinese city has experienced such dramatic shifts and such a rapid succession of widely different regimes. Moreover, Harbin grew from a small ,place for drying fishing nets" ${ }^{\prime 24}$, that is a remote fishing village among the reeds of the Songhua

agreed to cooperate with the PKW in Vladivostok. The two centers began to muster their forces in various parts of Siberia and Manchuria, their main task being to arrange for the liberation of Poles from Russian sovereignty, to secure them the status of foreigners in Russia, and then - after the establishment of Polish state - to grant them Polish citizenship (IJP, AGNW, file no. 701/2/3, Report concerning Polish Army in Siberia, Supreme Command of the Polish Army, Warszawa, March 1919, p. 452; E. Kolodzies, Organizacje polskie $w$ Mandżurii $w$ latach 1917-1920, in: Polonia $w$ walce o niepodległość Rzeczypospolitej 1914-1921, ed. A. Koseski, Pułtusk 1999, pp. 195-203).

118 KP, ZS, file no. 3399, Polish island in the Yellow Sea, edited by Tadeusz Szukiewicz, 28 November 1949 , p. 2.

119 AAG, APP, file no. 65, „Tygodnik Polski”, no. 246, 1926, p. 17; Instytut Polski i Muzeum im. gen. Sikorskiego (IMPS: The Polish Institute and Sikorski Museum), Ambasada RP przy Stolicy Apostolskiej (ASA: Embassy of the Republic of Poland to the Holy See), file no. A.44.122/4, „Missiones Catholicae”, Rome, June 17, 1930, p. 17.

${ }^{120}$ AAG, APP, file no. 4, Report of the Organizational Council of Poles from Abroad, Warszawa, 1932, p. 50.

${ }^{121}$ AAN, MSZ, file no. 10389, Report on the Polish Colony in Harbin and Manchuria, written by Edward Skowroński, Polish Delegate in Harbin, on May 19, 1931.

122 „Echo z Dalekiego Wschodu”, no. 3, 1934, p. 17.

123 AAN, KPM, file no. 66, History of the Polish colony in Manchuria, edited by Kazimierz Krąkowski, pp. 103-110.

${ }^{124}$ A "place for drying fishing nets" is only one of many interpretations of the name "Harbin" (A. Grochowski, Polacy, p. 9; J.H. CARTer, Creating a Chinese Harbin. Nationalism in an International City, Ithaca 2002, pp. 14-15). Other expressions include: "fishing lake", "crossing place", 
River, into an international urban complex of beauty and sophistication ${ }^{125}$ with hundreds of thousands of residents ${ }^{126}$. In combination with the Russian colonial initiative, Manchuria as well as Harbin changed from a largely unsettled wilderness into a wealthy agricultural zone on its way to rapid industrialization ${ }^{127}$. Over the span of many years, Russian, Chinese, Jewish, Polish, German and Japanese merchants cooperated as well as competed under varying conditions of parity, or the lack of it, and began the extraction for export of the region's great natural wealth. In this way, one of China's least developed borderlands became the vanguard of modern transformation.

Despite intensive Russification, the Harbin Poles not only preserved their faith and language but also greatly contributed to the socio-economic development of Northeastern China ${ }^{128}$. After the downfall of the Russian Empire in 1917, the

"poor village" or even "large grave" (S. Clausen, S. Thøgersen, The Making of a Chinese City. History and Historiography in Harbin, Armonk 1995, pp. 17-22).

${ }^{125}$ Between the mid 1900s and the late 1920s, Harbin gained a wide array of nicknames encapsulating its dynamic growth in that period. The evaluation of the city ranged from "The Manchurian Paris", through "The Paris of the East", to "The Pearl of the Far East" or "The Pearl on the Swan's Neck", though its early twentieth-century reputation was that of an "Infectious Pit" (B.L. Putnam Weale, The Coming Struggle in Eastern Asia, London 1908, p. 115; Y. Liberman, My China. Jewish Life in the Orient, 1900-1950, Jerusalem 1998, p. 16; O. ВАKICH, Russian City in China: Harbin before 1917, „Canadian Slavonic Papers”, vol. 28, no. 2, March 1985, p. 131; M. MeYER, In Manchuria, p. 115).

${ }^{126}$ By 1935, Harbin had become an established multiethnic city with over 450,000 inhabitants (E.J. Reyman, Encyklopedia nauk politycznych, vol. 3, Warszawa 1938, p. 866). However, the process of transformation into an international urban center was launched much earlier. In 1913, Harbin-owing to the construction and maintenance work on the Chinese Eastern Railway-had a total of 68,549 people, mostly of Russian as well as Chinese descent. There were a total of 53 different nationalities. Along with Russian and Chinese, there were 45 spoken languages used in Harbin at the time. Only $11.5 \%$ of all residents were born in Harbin (O. BAKICH, Emigré Identity: The Case of Harbin, „The South Atlantic Quarterly”, vol. 99, no. 1, Winter 2000, pp. 51-69). According to the census of May 15, 1903, construction of CER had already brought a population of 83,000 to the railway zone, 44,576 of whom were recorded as residents of Harbin. But only 15,579 were Russians, and approximately a third of these were women. Chinese made up slightly more than 28,000 (О.Г. Гончаренко, Русский Харбин, Москва 2009, pp. 35-64).

127 Yet, early Harbin, like all pioneer towns, was not an inviting place. The railway station was built several kilometers from the Songhua (J. NeJA, Harbin jako przestrzeń życia $i$ działalności Polonii mandżurskiej, in: Polskie ślady na Dalekim Wschodzie, p. 52). Furthermore, the roads connecting the old town with the commercial district were not paved. There was no sewage system. Life in Harbin was expensive, as everything was imported at great cost (L. Victoir, V. ZatsePine, Harbin to Hanoi, p. 21). It was far from other Russian towns and did not have the amenities available to various nationalities of the multinational Russian Empire in well-established Siberian settlements. In 1904, Józef Gieysztor, a Polish naturalist and economist, investigating the financial importance of Manchuria and eastern Mongolia on behalf of the Chinese Eastern Railway administration, described Harbin as a lonely steppe with marshland (E. KAJDAŃSKI, Wspomnienia, p. 24).

${ }^{128}$ AAN, KPM, file no. 1, Military Union of Poles in Manchuria, Statute, May 27, 1917, pp. 1-4. 
majority of Poles in Harbin decided to apply for Polish citizenship and retained it during the entire existence of Polish community in Manchuria. In 1931, for instance, approximately 1,685 Poles (82.81\%) residing in Harbin possessed Polish citizenship. Passports of other countries were obtained mainly due to financial reasons. Accordingly, 70 Poles (3.44\%) accepted the citizenship of the Soviet Union, 58 Poles (2.85\%) received Chinese citizenship, while 222 people of Polish origin $(10.90 \%)$ declared themselves as stateless ${ }^{129}$. The main pillars of Polish settlement in Manchuria, apart from the Chinese Eastern Railway, were the Polish Diplomatic Mission, the Polish Catholic Mission, various charity organizations, especially the so-called Polish Tavern (Gospoda Polska), and a large group of private entrepreneurs ${ }^{130}$.

The Polish-Soviet War in mid-1920 further worsened the plight of Poles in the Far East. In 1920, Polish officials, led by Józef Targowski, visited Manchuria. Autonomous local Polish organizations were abolished. The task of looking after a number of Poles scattered over the entire region was taken over by Polish Diplomatic Missions in Harbin and Vladivostok ${ }^{131}$. Meanwhile, those who could afford to do so left the Far East at their own expense, on ships leased by the Polish government from China and Japan ${ }^{132}$. The Polish Diplomatic Mission in Harbin was, in fact, a Polish consular office operating between 1920 and 1941. The diplomatic post was established in order to protect the economic interests of Polish businessmen in Manchuria and for the benefit of the Polish community involved in the management of the Chinese Eastern Railway, without formal approval of the local authorities ${ }^{133}$. Over the years, the diplomatic mission was referred to as a Consulate (1920-1924), the Delegation of the Republic of Poland (1924-1939) and a Consulate General (1939-1941). Its territorial and factual competences as well as objectives also changed several times. First, the post was under direct supervision

${ }^{129}$ AAN, Konsulat Generalny RP w Charbinie [KGRP: The Consulate General of the Republic of Poland in Harbin], file no. 5, List of Polish communities abroad, correspondence, February 21, 1931, pp. $1-2$.

130 J. Neja, Polacy w Mandżurii, „Biuletyn Instytutu Pamięci Narodowej”, no. 3, 2002, p. 34.

131 IJP, AGNW, file no. 701/2/31, Telegram of Józef Targowski to the Ministry of Foreign Affairs in Warsaw, Harbin, April 2, 1920, p. 203.

132 The problem of repatriation was finally solved on 14 December 1924, when Poland and Soviet Russia signed an agreement according to which Russia permitted Polish repatriates from the territory of the Russian Far East to be transported across central Russia. In return for this, Poland at last agreed to recognize the Soviet Union. The long process of repatriation was completed only in 1924, when most of the remaining Poles living in Siberia and Manchuria returned to their newly independent homeland (K. Symonolewicz, Miraże, p. 267).

133 W. SKóRA, Organizacja i pierwszy okres działalności polskich konsulatów w Harbinie i Władywostoku w latach 1920-1924, in: Polskie ślady na Dalekim Wschodzie, pp. 75-90. 
of the Polish Legation in Tokyo, then the Polish Legation in Shanghai, and finally, the Ministry of Foreign Affairs in Warsaw ${ }^{134}$. The Polish Diplomatic Mission in Harbin was led by a stream of dedicated and sensible diplomats, such as Michał Morgulec (1920-1922) $)^{135}$, Karol Pindór (1922-1928) ${ }^{136}$, Konstanty Symonolewicz $(1929-1930)^{137}$, Edward Skowroński (1930-1931), James Douglas (1931-1933) ${ }^{138}$, Aleksander Kwiatkowski (1932-1938) ${ }^{139}$ and Jerzy Bogumił Litewski (1938-1941) ${ }^{140}$. Following a close cooperation between Poland and Japan in the early 1930s, Polish consulate in Harbin became involved in the operations of Polish intelligence that were often coordinated with the actions of Japanese spy services. The bilateral cooperation was aimed at providing an effective defense against the Soviet Union ${ }^{141}$. Interestingly, members of the Polish consular service in Harbin, especially Władysław Pelc (1906-2002), were also responsible for consistent cooperation with other diaspora communities in Manchuria, mostly Ukrainian, Tatar and Georgian settlers $^{142}$. However, the Polish Diplomatic Mission in Harbin terminated its acti-

134 M. Mroczkowska, K. Szczepaniak, Stosunki dyplomatyczne Polski. Informator, vol. 3: Azja, Zakaukazie, Australia i Oceania 1918-2009, Warszawa 2010, p. 45; W. SкóRA, Placówki MSZ, pp. 700-717.

135 S. ŁozA, Czy wiesz kto to jest?, Warszawa 1938, p. 502; Odznaczenie chińskie dla P. Patka, „Gazeta Lwowska”, no. 132, June 12, 1928, p. 1.

136 J. GoleC, S. Bojda, Stownik biograficzny ziemi cieszyńskiej, vol. 2, Cieszyn 1995, pp. 179-180.

137 AAN, Prezydium Rady Ministrów (PRM: Presidium of the Council of Ministers), file no. VIII-255, Personal records, 1931, pp. 123-124. Konstanty Symonolewicz (1884-1952), undoubtedly, was one of the highest rated Polish diplomats in Harbin by members of the local diaspora. Symonolewicz started his career as an employee of the Russian consular service in which he worked as an official in the Russian diplomatic mission in Beijing (1912). Between 1913 and 1920, he served as a consular official in Qiqihar. In the same year, he began working for the Polish foreign service. He was entrusted with the following functions in Harbin (1920-1930): Secretary of the Consulate, Vice-consul, Consul, Deputy Delegate of the Polish Republic in China, Head of the Polish Delegation in Harbin, and de facto Head of the Consulate in Harbin (1928-1930). Furthermore, Symonolewicz wrote two books dealing with the Polish settlement in China, namely Miraże mandzurskie, Warszawa 1932 and Moi Chińczycy. 18 lat w Chinach, Warszawa 1938 (S. ŁozA, Czy wiesz, p. 710; W. SkóRA, Stużba konsularna Drugiej Rzeczypospolitej. Organizacja, kadry i działalność, Toruń 2006, p. 342).

138 CAW, Akta Personalne i Odznaczeniowe (APO: Personal Records and Decorations), file no. KN 2.08.1931, Collection of Personal Records, p. 1.

139 AAN, PRM, file no. VIII-247, Personal records, 1931, p. 109-110; P. Łossowski, Historia dyplomacji polskiej, vol. 4: 1918-1939, Warszawa 1995, p. 46; W. SKóRA, Stużba konsularna, p. 105.

140 Wybory Delegata na III Zjazd Polaków z Zagranicy, „Tygodnik Polski”, no. 23, June 4, 1939 , p. 3.

${ }^{141}$ H. KuromiYa, A. PePeoński, Między Warszawa, pp. 327-431.

142 In 1932, Władysław Pelc, collaborator of Polish intelligence and former resident of Harbin, came there with a special mission. The goal of his task was to work slowly towards the unification and revitalization of activities conducted by local Ukrainians, Georgians and Tatars, as part of the mobilization of the Promethean movement in Manchuria (Biblioteka Polska w Paryżu [BPP: Polish Library in Paris], Archiwum Władysława Pelca [AWP: Władysław Pelc Collection], file no. 1, Cur- 
vities in December 1941, as soon as consul Jerzy Litewski was evacuated from Manchuria to Japan, and then transported to London in November $1942^{143}$.

As in most Polish settlements around the world, the Catholic Church played an important role within Polish community in Manchuria, raising funds for charity ideas, not to mention supporting spiritual and material needs of its followers. During the early years of Harbin's existence, many Catholics turned to the French Catholic missions for their spiritual needs ${ }^{144}$. However, local Poles decided to build their own church. In 1901, Church Committee, including Seweryn Wachowski, Stanisław Gabriel, Wacław Łazarski and Władysław Rembertowicz ${ }^{145}$, was established to raise the necessary funds for the construction of a Catholic church in Harbin ${ }^{146}$. The Committee and its volunteers organized a variety of charitable events, such as lotteries, plays and costume balls, in order to collect donations ${ }^{147}$. The cornerstone for a new neo-Gothic style church was placed on 7th November 1906 on a lot handed over by the Chinese Eastern Railway management ${ }^{148}$. In this way, the construction of a Catholic church began and was completed rather quickly in the following year ${ }^{149}$. Between 1901 and 1907, the Chinese Eastern Railway company allowed the city's Polish community to use one of its buildings as a chapel and Fr. Adam Szpiganowicz, Polish military chaplain, was responsible for the celebration of religious services ${ }^{150}$.

riculum Vitae, p. 2). Pelc, who could communicate in Chinese, Ukrainian, Russian and English, was one of the actual creators of the Promethean Club in Harbin (CAW, OIISG, file no. I.303.4.5614, Prominent members of the Promethean movement, August 17, 1934, p. 4). Formally, however, he was the secretary of the Polish Chamber of Commerce in Harbin. In fact, he worked under direct supervision of Aleksander Kwiatkowski (CAW, OIISG, file no. I.303.4.5570, The Polish Chamber of Commerce in Harbin, April 15, 1934, p. 2-3).

143 Polska stużba zagraniczna po 1 września 1939 r., Londyn 1954, p. 113.

144 French missionaries served in Manchuria since the fifteenth century. The prayers at the French mission were, of course, conducted either in French or Latin. Thus, Polish Catholics had a limited access to priests, religious services and ceremonies, such as marriage, baptism or the First Communion (Historia Parafii Polsko Katolickiej w Charbinie (Chiny), „Pamiętnik Charbiński”, vol. 1, 1923, p. 22; J. Bukowicz, T. GóRski, Marianie 1673-1973, Rzym 1975, pp. 244-268; J. TyCzKA, Na wschodzie i na zachodzie, Warszawa 2003, pp. 77-85).

${ }^{145}$ K. Grochowski, Polacy, p. 19.

146 K.Y. Deog, Kolonia, p. 67.

147 K. Grochowski, Polacy, p. 17; J. Szymański, Opieka duszpasterska nad Polakami w Harbinie, „Studia Polonijne”, vol. 38, 2017, p. 40.

148 J. KIL, K. GraczyK, Kolonia polska w Mandżurii - analiza historycznoprawna, „Z Dziejów Prawa", vol. 6(14), 2013, p. 124.

149 AAN, KPM, file no. 16, The Polish Guardian Committee, Documents certifying ownership of the church buildings in Harbin, 1922, p. 120; M. CABANOwski, Tajemnice, p. 16.

150 Historia Parafii Polsko Katolickiej w Charbinie (Chiny), „Pamiętnik Charbiński”, vol. 1, 1923, p. 23. 
In 1921, Jean-Baptiste-Marie Budes de Guébriant (1860-1935) ${ }^{151}$, Superior General of La Société des Missions Etrangères ${ }^{152}$, came to Harbin and Vladivostok as an apostolic visitor appointed directly by the Pope Benedict $X V^{153}$. The Bishop was warmly welcomed, among other officials, by Michał Morgulec, Polish consul in Harbin $^{154}$, and clergy present in the city ${ }^{155}$. During his stay, on 14th June 1921, Bishop de Guébriant came to the conclusion that the number of Catholics in the city had grown significantly and that St. Stanislaus Church could no longer accommodate all of them. His wish to build a second Catholic church was fulfilled with assistance of the Chinese Eastern Railway enterprise and a number of Polish businessmen ${ }^{156}$. The solemn dedication of the future church took place on 3rd September 1922. By then, another Church Building Committee was established, headed by Władysław Kowalski, who personally donated the sum of 4,000 mexican dollars ${ }^{157}$. In 1925 , the church building was completed and named in honor of St. Josaphat ${ }^{158}$.

The Polish Catholic Mission in Harbin existed from the beginning of the twentieth century to the demise of the Polish community in late 1950s and managed to initiate several useful institutions, such as the St. Vincent de Paul Society (1909), a primary school (1912), a shelter for homeless and elderly, and a small parish library (1913). However, its greatest achievement involved a successful opening of the Polish secondary school on 3rd September 1915, which was renamed to the Henryk Sienkiewicz Secondary School ${ }^{159}$ in the following year ${ }^{160}$. All the same, Harbin was not a religiously homogeneous place ${ }^{161}$. The city boasted Muslim mosques, Jewish synagogues, Protestant churches for Baptists and Lutherans,

151 A. Hastings, A World History of Christianity, London 1999, p. 396.

152 G.H. ANDERson, Biographical Dictionary of Christian Missions, Grand Rapids 1999, pp. 267268.

153 J. KIL, K. GraczyK, Kolonia, p. 125.

154 Rozwój stosunków polsko-chińskich (1917-1936), „Polityka Narodów”, vol. X, no. 3, 1937, p. 148; Rocznik Stużby Zagranicznej RP, Warszawa 1935, p. 85.

${ }^{155}$ K. Grochowski, Polacy, p. 31.

156 Ibidem, pp. 32-34.

157 At the time, 1 Mexican dollar equaled approximately $1 / 2$ US dollars. The total cost of the church building was estimated at 14,000 Mexican dollars (A. MAJDOwSKI, Kościót katolicki w cesarstwie rosyjskim. Syberia, Daleki Wschód, Azja Środkowa, Warszawa 2001, p. 232).

158 B.Z. Wojas, Dzieje Polonii Charbińskiej, „Zeszyty Historyczne”, vol. 30(250), 1974, p. 13.

159 Both the Henryk Sienkiewicz Secondary School and the Polish Tavern received financial support from the Polish government in 1920s and 1930s (AAN, MSZ, file no. 5963, Report on Polish school in Harbin, pp. 1-12).

160 AAN, KPM, file no. 16, The Polish Guardian Committee, documents certifying ownership of the church buildings in Harbin, 1922, p. 120.

${ }^{161}$ In 1922, the number of Catholics in Harbin was estimated at 9,500 people, of which Poles accounted for 4,000 believers, and the Chinese constituted 5,565 followers of the Roman Catholic Church. In 1930, however, the total number of Catholics declined to 8,500 followers, of which Poles 
Buddhist temples, and many ethnic associations grouping the local nationalities ${ }^{162}$. Although Polish residents of Harbin formed a close group, consisting primarily of Catholics, they were not religiously homogeneous.

Table 3: Religious distribution of Polish settlers in Harbin, 1930

\begin{tabular}{|l|c|c|}
\hline \multicolumn{1}{|c|}{ Religious conviction } & Number of believers & Percentage of believers \\
\hline Catholics & 1696 & 83.34 \\
\hline Greek Catholics & 7 & 0.34 \\
\hline Orthodox & 114 & 5.60 \\
\hline Karaites & 4 & 0.20 \\
\hline Jews & 200 & 9.83 \\
\hline Protestants & 14 & 0.69 \\
\hline Total & 2035 & 100 \\
\hline
\end{tabular}

Source: AAN, MSZ, file no. 10389, The Polish colony in Harbin and Manchuria. Report of Edward Skowroński, Polish Delegate in Harbin, May 19, 1931.

The Polish community in Manchuria was highly organized and boasted numerous social, cultural as well as educational associations, including schools which provided tuition in the Polish language at both elementary and lower-secondary levels ${ }^{163}$. Moreover, Polish residents of Harbin, usually with great eagerness, established various businesses, such as factories ${ }^{164}$, industrial enterprises, restaurants, import-export offices, workshops, warehouses, bakeries and shops ${ }^{165}$. Those with less means, as well as the younger generation, including neophyte entrepreneurs, found employment among the affluent representatives of the community. The more destitute were assisted, first on an individual basis, and then gradually, by organized church-supported charitable institutions and societies, including the

made up a group of 3,000 persons (IPMS, ASA, file no. A.44.122/4, Letter of Władysław Skrzyński to Cardinal Eugene Pacelli, Rome, June 20, 1930, p. 30).

162 CAW, OIISG, file no. I.303.4.5443, Study of political relations in the Far East, 1936, p. 74.

163 KP, ZS, file no. 3399, Polish island in the Yellow Sea, edited by Tadeusz Szukiewicz, 28 November 1949, pp. 3-4.

164 „Tygodnik Polski”, no. 15, April 9, 1939, p. 7.

165 „Listy Harbińskie. Numer Noworoczny”, no. 1, January 1, 1932, p. 8. 
Roman Catholic Charitable Society, which was set up in $1903^{166}$. Equally helpful was the association Polish Tavern ${ }^{167}$. This organization not only provided financial support, but also helped to settle disputes among different members of the Polish community and went as far as developing specific forms of justice, such as the Citizens Jury (Sąd Obywatelski) ${ }^{168}$ and the Court of Honor (Sąd Honorowy) ${ }^{169}$. These legal institutions were commonly made up of highly respected individuals with relevant knowledge and a possible interest in the outcome of a given proceeding ${ }^{170}$. In 1927, for instance, the Court of Honor was composed of Fr. Gerard Piotrowski, Władysław Kowalski, M. Fabisiak and F. Chmielewski ${ }^{171}$. However, they decided about trivial matters, which raised little controversies. In contrast, Polish Tavern coordinated activities of other Polish associations in Manchuria and therefore was perceived as a safe haven by many Poles in the region ${ }^{172}$.

For many Polish settlers, especially within the Russian Empire, who were confined for more than a century to live under the harsh rule of neighboring empires, Manchuria was the land of opportunity. Eventually, some of them would spread further and become instrumental in the development of Polish companies across the region ${ }^{173}$. Inevitably, the most influential Polish businessman in Northeastern

166 Stowarzyszenia polskie w Charbinie, „Pamiętnik Charbiński”, vol. 1, 1923, p. 18. The Roman Catholic Charitable Society was the first officially recognized Polish association in Harbin and Manchuria. However, the first unofficial Polish society in Harbin, called the Church Committee, was established in 1901. Its main goal was connected with raising funds for construction of a Catholic church in Harbin (A. Grochowski, Polacy, p. 73).

167 The Polish Tavern was a social, cultural and educational association operating in Harbin from 1907 to 1949, although it was initially involved in gastronomy („Praca. Pismo Postępowe Demoktratyczne", no. 8, May 12, 1918, p. 10). This association initiated the first Polish school, organized language courses for the Polish community and charity fundraising. Further, organized charity balls, among other cultural activities, and strived at integrating the whole community. The association was divided into several sections dedicated to education, work with youth (Polish Youth Association), culture (Theater Group), and sports (hockey, volleyball, football and yachting teams). The Polish Tavern was the first Polish secular association in Harbin (KP, ZS, file no. 3390, Memories from the years of youth in Harbin (1921-1945), edited by Emilia Czajewska, Szczecin 1985, p. 6; A. GroCHOwski, Polacy, pp. 54-62; J. NeJA, Harbin, pp. 58-65).

168 K. Frycz, Wyrok Sądu Obywatelskiego, „Listy Polskie z Dalekiego Wschodu”, no. 7, July 7, 1918, pp. 8-13.

169 AAN, KPM, file no. 28, The Association "Polish Tavern" in Harbin, pp. 5-8.

170 AAN, KPM, file no. 11, The weekly „Polish Letters from the Far East” issued by the Polish Political Council of the Far East and Eastern Siberia, pp. 89-93.

171 A. Grochowski, Polacy, p. 62.

172 AAG, APP, file no. 4, Report of the Organizational Council of Poles from Abroad, Warszawa 1932, p. 3.

${ }^{173}$ W. Komorowski, Daleki Wschód w międzynarodowej polityce gospodarczej, Warszawa 1931, pp. 316-317. 
China, conducting his economic activities under various names, such as Leśne Przedsiębiorstwo W. Kowalskiego (Timber Company of W. Kowalski), V. F. Kovalsky, or simply Yablonia Timber Company ${ }^{174}$, was Władysław Kowalski ${ }^{175}$. Nevertheless, other merchants, entrepreneurs and specialists of Polish origin also had a fair share in the exploration of Manchurian market and their natural resources ${ }^{176}$. The early years of Harbin's existence were marked by increased activity of Polish entrepreneurs. Thus, Adam Czajewski founded a vodka distillery in Harbin ${ }^{177}$. A family of Polish Karaites, namely Eliasz Łopatto and Abram Łopatto, focused on the tobacco industry and established the first factory of cigarettes, one of the largest in China ${ }^{178}$.

In addition, Michał Wróblewski started the first large-scale beer brewery in that region ${ }^{179}$. Wróblewski, a brewer from Pomerania, made a stunning career in Manchuria and became a philanthropist within the Polish community in Harbin. Another company founded by Poles, namely Władysław Kowalski and Dynowski, developed the first steam-driven mills ${ }^{180}$. Furthermore, Bohdan Broniewski built a substantial sugar factory in a small town called Acheng (26 miles east of Harbin) ${ }^{181}$, for which the equipment was supplied by a Polish firm called Szpotański, Borman and Swede, as well as another Polish company, that is a steam boilers factory owned by Krasiński ${ }^{182}$. Apart from the equipment, many specialist were brought from Poland to work in the sugar company ${ }^{183}$. The sugar beet cultivation,

174 H.T. Montague Bell, H.G.W. Woodhead, The China Year Book 1919, London 1919, p. 101; H.G.W. Woodhead, H.T. Montague Bell, The China Year Book 1921, Tientsin 1922, p. 782.

${ }^{175}$ K.Y. DeOG, Kolonia, pp. 47-48.

176 W. SKóRA, Sytuacja materialna Polonii mandżurskiej w 1929 roku (w świetle raportu konsula RP Konstantego Symonolewicza), „Przegląd Orientalistyczny”, no. 3-4, 2010, pp. 125-135.

177 M. Kaluski, Polacy w Chinach, p. 41.

178 These two wealthy Harbiners of Trakai origin often sent considerable sums of money to support the Polish Karaites of Vilnius and Trakai in the 1920s. In 1936 the group of Polish Karaites in Harbin organized the Society of the Polish Karaites in Manchukuo. The Polish consul agreed to support the Society and helped to register it with the government of the country (M. KiziLov, The Sons of Scripture. The Karaites in Poland and Lithuania in the Twentieth Century, Warsaw 2015, pp. 189-190).

179 KP, ZS, file no. 3392, Extracts from the land and mortgage registers, 1917-1939, pp. 1-12.

180 M. CABAnowski, Tajemnice Mandżurii, pp. 12-13.

181 S.R. WAGEL, Finance in China, Shanghai p. 488.

182 CAW, OIISG, file no. I.303.4.4476, Report from the visitation of Manchuria, written by Lt. Col. W. Jędrzejewicz, September 30, 1925, pp. 7-8.

183 Interestingly, the Acheng Sugar Factory in Harbin, Heilongjiang Province, was China's first sugar company, founded in 1905 by a Polish businessman. Its initial capital amounted almost 1 million rubles. After 1949, Acheng had become a pillar of the planned economy, the largest sugar plant in China, producing 3,000 tons of beet sugar a day. However, it was old, burdened with debt, and unable to compete with more efficient producers. In 1998, Acheng became China's first major 
however, took place in Manchuria ${ }^{184}$. In this way, a group of Polish managers introduced sugar beet cultivation to the Chinese farmers of the area, which was previously unknown in China ${ }^{185}$. Hundreds, if not thousands, of Polish entrepreneurs and traders who operated on a much smaller scale remain largely unrevealed ${ }^{186}$.

In 1899, Kowalski, together with Frank and Kiliański, was among the first businessmen who began the timber industry in Manchuria. In the first decades of the twentieth century, Kowalski became one of the most important contractors of the Chinese Eastern Railway and the richest entrepreneur in North China ${ }^{187}$. From 1903 to 1906, Kowalski was engaged in the construction of several steam flour mills in Harbin ${ }^{188}$. Back then the first place in manufacturing industry across Manchuria was taken by flour-milling ${ }^{189}$. In early 1920 s, the railway zone contained in all 35 flourmills, which milled up to 300,000 tons of wheat. At least 24 of these mills were situated in Harbin and approximately six were owned by Władysław Kowalski. Besides flour, his mills produced manna and buckwheat grits. Out of the flour produced, about $2 / 3$ were brought to the CER beltway and the remaining $1 / 3$ was consumed directly at the points, where the mills were located ${ }^{190}$.

In 1911, Kowalski received his first official timber concession from the local authorities and called it Yablonia. All of his timber concessions covered an area of approximately $6,157 \mathrm{~km}^{2}$, and stretched along eastern line of The Chinese Eastern Railway ${ }^{191}$, which connected Harbin and Nikolsk-Ussuriysky ${ }^{192}$. At its peak in the beginning of 1925, his company provided employment for almost 10,000 workers across northern parts of Manchuria ${ }^{193}$, including Poles, Russians and the Chinese. Moreover, the reserve stock of timber, especially firs, pines, cedars and

bankruptcy, putting 4,500 employees out of work (Y. CAI, State and Laid-off Workers in Reform China: The Silence and Collective Action of the Retrenched, London 2006, p. 80).

184 B.Z. Wojas, Dzieje Polonii, p. 9.

185 R.K.I. QuESTED, “Matey” Imperialists: the Tsarist Russians in Manchuria 1895-1917, Hong Kong: University of Hong Kong Press 1982, p. 211; A. Winiarz, Gtówne kierunki, p. 34.

186 A. Grochowski, Polacy, p. 192; M.R. Ristaino, Port of Last Resort. The Diaspora Communities of Shanghai, Stanford 2001, pp. 29-30.

187 I.A. Mikhollov, North Manchuria and the Chinese Eastern Railway, Harbin: Chinese Eastern Railway Company 1924, pp. 181-183; F. PATRIKeEFF, Russian Politics in Exile. The Northeast Asian Balance of Power, 1924-1931, Oxford 2002, p. 200.

188 Milling in Manchuria, „American Miller and Processor”, no. 1-6, vol. 38, 1910, p. 309.

189 Milling in Manchuria, „The Northwestern Miller”, no. 76, 1908, p. 155.

190 Economical Bureau of CER, The Chinese Eastern Railway and its Zone, Harbin: Chinese Eastern Railway Company 1923, p. 21.

${ }^{191}$ CAW, OIISG, file no. I.303.4.4432, Survey of Manchuria, September 30, 1925, p. 8.

192 AAN, KPM, file no. 11, Fragment of announcement in the weekly „Listy Polskie z Dalekiego Wschodu" (lack of date and pagination).

${ }^{193}$ H. Kuromiya, A. Peploński, Między Warszawa, p. 317. 
oaks, across his concessions was estimated at nearly one billion cubic feet ${ }^{194}$. This area produced fire-wood, larch wood sleepers, telegraph poles and supporting stanchions for mines. Interestingly, between 1921 and 1924, Kowalski also leased a mining concession from the local government ${ }^{195}$. The scale of his establishment was best evidenced by a wide range of expenses incurred during the initial years of its implementation. By 1923, Władysław Kowalski had invested a total sum of $10,100,000$ dollars in his enterprises within the entire region ${ }^{196}$.

In 1936, the Japanese authorities, despite frequent protests of Polish diplomatic missions in Harbin and Tokyo ${ }^{197}$, took over timber concessions previously awarded to Władysław Kowalski. In the end, Kowalski, bankrupt and brought to a state of extreme nervous exhaustion, died of a heart attack on November 22, 1940 in Harbin $^{198}$. His wife and two daughters, however, left Manchuria in the following year. Identical measures were adopted in case of mining concession, with an area of 4,000 square kilometers ${ }^{199}$, belonging to Kazimierz Grochowski ${ }^{200}$.

In 1909, Kazimierz Grochowski came to the vicinity of the Zeya River, and started working for the international concern called the Upper Amur Gold Mining Company, which at the time was a thriving joint stock company with French and German capital. The company was primarily dealing with a large-scale exploration as well as extraction of gold. In the summer of 1915, however, Kazimierz Grochowski decided to leave the Upper Amur Gold Mining Company, and less than a year later acquired a mining concession from the Mongolian authorities on February 17, 1916. The concession, covering an area of approximately $4,000 \mathrm{~km}^{2}$ in Hulunbuir, was eventually approved by the Russian Vice-Consul in Hailar on 29th July 1916. Thus, Grochowski was granted the right to extract, along with other natural resources, oil, coal and gold, especially around the Khalkhyn Gol River in Inner Mongolia. Shortly after receiving concession rights, he was able to open a coal mine, quickly followed by salt and soda processing plants ${ }^{201}$. Unfortunately,

194 At the time, the reserve stock of timber in North Manchuria was estimated at 136 billions of cubic feet. Out of this quantity only one thirty fourth part (4 billions) was actually exploited (Economical Bureau of CER, The Chinese, p. 17; K. Grochowski, Polacy, p. 192).

195 Economical Bureau of CER, The Chinese, p. 18.

196 K. Grochowski, Polacy, p. 193.

197 CAW, OIISG, file no. I.303.4.2015, Report on the attitude of Japanese authorities towards Polish citizens in Manchukuo. September 22, 1937, pp. 1-2.

198 A. WiniarZ, Główne kierunki, p. 43.

199 „Echo z Dalekiego Wschodu”, no. 3, 1939, p. 17.

200 A. Aleksandrowicz, Mandżuria, p. 167.

201 CAW, OIISG, file no. I.303.4.2015, Copy of the concession agreement signed by Kazimierz Grochowski, translated from the Mongolian language, June 6, 1937. The concession agreement was 
Kazimierz Grochowski irretrievably lost his mining concession in $1936^{202}$, which was part of a wider plan, developed by the Japanese, for economic and military conquest of Manchuria, and consistently implemented at least since $1935^{203}$.

When the Japanese Empire entered the Second World War, following a surprise military strike by the Imperial Japanese Navy against the United States naval base at Pearl Harbor on the morning of 7 December $1941^{204}$, the Polish Diplomatic Mission in Harbin, at the time operating as a Polish Consulate General, was closed. Nevertheless, the former consul, Jerzy Litewski, managed to form the Polish Guardian Committee in order to secure the material welfare of the Polish residents of Harbin, especially the Henryk Sienkiewicz Secondary School, by taxing members of the community ${ }^{205}$. Afterwards, Jerzy Litewski was transported to Tokyo, from where he joined the Polish government-in-exile in London. Between 1944 and 1945, he was given the post of Polish consul in Bombay ${ }^{206}$. The Polish Guardian Committee was led by Albin Czyżewski as well as its secretary Aleksander Macedoński ${ }^{207}$. The Committee was officially recognized by the Manchukuo government on 1 January $1942^{208}$. As a result of political pressure from Japan and Germany, the lives of European settlers, including the Polish diaspora, and the local Chinese became significantly more difficult. Rationing cards were introduced for local provisions. All the inhabitants of Manchukuo had to possess three so-called "residence cards", renewed annually, and carry as well yellow cards with a number, and that same number had to appear on the doors of their residences $^{209}$. One of the last Polish organizations in Northeastern China, that is the Polish Citizens' Committee in Manchuria, was established on 23 September 1945, immediately after the successful Soviet occupation of Harbin ${ }^{210}$.

the basis of his efforts to recognize his ownership over the concession by the Manchukuo authorities, pp. 7-8.

${ }^{202}$ Similar measures were used against a number of European businessmen within other branches of Manchurian economy, such as soybean industry (Le soja: Nationalisation de cette industrie au Mandchoukouo, „Revue Internationale des Produits Coloniaux et du Matérial Colonial”, vol. 14, no. $164-166,1939$, pp. 259-262).

203 CAW, OIISG, file no. I.303.4.3145, Current Economic Report No. 1/35, pp. 685-686.

204 G.W. Prange, D.M. Goldstein, K.V. Dillon, December 7, 1941. The Day the Japanese Attacked Pearl Harbor, New York 1988, p. 174.

205 A. Winiarz, Działalność Polskiego Komitetu Opiekuńczego w Harbinie (1942-1945), „Rocznik Polonijny” 1984-1985, pp. 197-198.

206 Polska stużba zagraniczna po 1 września 1939 r., p. 113.

207 B.Z. Wojas, Dzieje, p. 12.

208 AAN, KPM, file no. 16, Polish Guardian Committee, Protocol no. 1, Organizational matters, January 12, 1942 (lack of pagination).

209 K.Y. Deog, Kolonia, p. 64.

210 W. Pelc, Mandżurska Polonia, p. 35. 
In a similar way to the previous committee it was headed by Albin Czyżewski ${ }^{211}$ and his assistant Aleksander Macedoński. Soon, however, they were replaced by Kazimierz Krąkowski, a Polish communist who gained the support of local Soviet administration. In the early days of Soviet presence in Harbin, Aleksander Macedoński was arrested by the People's Commissariat for Internal Affairs, taken to the USSR, accused of espionage and sentenced to many years of forced labor ${ }^{212}$. The most probable cause of his detention was that he studied in Japan before the outbreak of the Second World War and his knowledge of the Japanese language ${ }^{213}$. Ultimately, like many prisoners of the Kolyma forced-labor camps ${ }^{214}$, Macedoński came back to Poland exhausted both physically as well as mentally in 1959 and died shortly after his return ${ }^{215}$.

The Polish Citizens' Committee in Manchuria, despite its early promises that it would take up the matter of emigration to Poland, did very little to fulfill its obligations. Not until the period of 1947-1948 did a branch of the Polish Citizens' Committee, called the Polish Temporary Committee in Manchuria, put in order the files of numerous Poles and individuals applying for Polish citizenship. This registration indicated that $80 \%$ of representatives of the Polish community in Harbin declared for return to Poland. On the contrary, $12 \%$ of the Poles living in Harbin did not want to leave due to an old age or illness, while $8 \%$ gave no reason ${ }^{216}$. Eventually, a Polish delegation, headed by Jerzy Kłosowski, came from Warsaw in 1949 with the aim of organizing the repatriation. The delegation received support from the Chinese authorities which wanted to get rid of various foreigners as fast as possible. As a result, on the 3rd and 12th day of July, 1949, rail transports headed towards Poland, each carrying around 400 passengers. The Polish government's Liquidation Group left Harbin on July 24, 1949. In December 1950 another group of 200 individuals returned, on a Polish merchant vessel ${ }^{217}$.

By the late 1950s, turbulent political developments, including the Soviet occupation of Manchuria between 1945 and 1946, not to mention the Chinese Revo-

211 A. Winiarz, Działalność, pp. 204-205.

212 AAN, KPM, file no. 19, A statement of the Polish Citizens' Committee in Manchuria on the detention of Aleksander Macedoński, October 31, 1945, p. 382; AAN, KPM, Letter from the mother of Aleksander Macedoński to the Military Prosecutor in Harbin, October 31, 1945, p. 383.

${ }^{213}$ AAN, KGRP, file no. 16, Personal files of Aleksander Macedoński, 1933-1941, p. 14.

214 J. NeJA, Harbin jako, p. 71.

215 E. KAJDAŃSKI, Korytarz, p. 173.

216 AAN, KPM, file no. 22, Polish Temporary Committee in Manchuria, Protocols, Notices, 1947-1948 (lack of pagination); AAN, KPM, file no. 23, Polish Temporary Committee in Manchuria, Protocols, Messages, Correspondence, 1948 (lack of pagination).

217 AAN, KPM, file no. 66, History of the Polish colony in Manchuria, edited by Kazimierz Krąkowski, p. 110. 
lution in 1949, had driven most Poles out of China. But for many of them, their roots in China became a key aspect of their identity in emigration as well as their professional lives. When antireligious repression was at its peak in 1957, the last two priests, namely Aleksander Eysymontt and Gracjan Kołodziejczy left Harbin for Australia. The others left for Australia, Brazil, Canada, Israel and the United States $^{218}$. Six years later the Association of Polish Citizens in China, numbering eighteen members, was dissolved. During the Maoist Cultural Revolution (19661976) most traces of Polish presence in Harbin were destroyed ${ }^{219}$.

\section{BIBLIOGRAPHY}

\section{Archival materials}

Archiwum Akt Nowych w Warszawie (Central Archives of Modern Records in Warsaw)

a) Kolonia Polska w Mandżurii (Polish Colony in Manchuria)

b) Konsulat Generalny RP w Charbinie (The Consulate General of the Republic of Poland in Harbin)

c) Ministerstwo Spraw Zagranicznych (Ministry of Foreign Affairs)

d) Prezydium Rady Ministrów (Presidium of the Council of Ministers)

Archiwum Archidiecezjalne w Gnieżnie (Archdiocesan Archive of Gniezno)

a) Archiwum Prymasa Polski (Primate of Poland Acts)

Biblioteka Polska w Paryżu (Polish Library in Paris)

a) Archiwum Władysława Pelca (Władysław Pelc Collection)

Centralne Archiwum Wojskowe w Warszawie (Central Military Archives in Warsaw)

a) Akta Personalne i Odznaczeniowe (Personal Records and Decorations)

b) Oddział II Sztabu Głównego (Generalnego) z lat 1921-1939 (The Second Department of Polish General Staff, 1921-1939)

Instytut Józefa Piłsudskiego w Ameryce (Józef Piłsudski Institute of America)

a) Adiutantura Generalna Naczelnego Wodza (Adjutancy-Commander in Chief)

b) Archiwum Józefa Piłsudskiego (Józef Piłsudski Acts)

Instytut Polski i Muzeum im. gen. Sikorskiego (The Polish Institute and Sikorski Museum)

a) Ambasada RP przy Stolicy Apostolskiej (Embassy of the Republic of Poland to the Holy See)

Książnica Pomorska w Szczecinie (Pomeranian Library in Szczecin)

a) Zbiory specjalne (Special Collections)

${ }^{218}$ KP, ZS, file no. 4420, Return to the Fatherland. Through the Nine Seas and Three Oceans, Lubań, September 1, 2013, pp. 1-5.

${ }^{219}$ K. Grochowski, Jeszcze o Polonii, p. 35. 


\section{Published materials}

Adams W.H.D., In the Far East: A Narrative of Exploration and Adventure in Cochin-China, Cambodia, Laos, and Siam, Edinburgh: Thomas Nelson and Sons 1879.

AleKsANDrowicz A., Mandżuria, jej przeszłość, teraźniejszość, kraj i ludzie, Warszawa: Biblioteka Polska 1937.

Anderson G.H., Biographical Dictionary of Christian Missions, Grand Rapids: W.B. Eerdmans Publishing 1999.

АндРЕЕ́вский И.Е., Энциклопедический словарь Брокгауза и Ефрона, т. 5а, СанктПетербург: Акционерное издательское общество Ф. А. Брокгауз-И. А. Ефрон 1892. Анучин В.А., Географические очерки Маньчжурии, Москва: Географгиз 1948.

Armstrong C.K., The North Korean Revolution, 1945-1950, Ithaca: Cornell University Press 2003.

Austin O.P., Trading with the Far East, Yokohama: The National City Bank of New York 1920.

АвАРин В.Я., Империализм в Манчжурии, tом I: Этапы империалистической борьбы за Манчжурию, Москва: ОГИЗ 1934.

BabBage C., On the Economy of Machinery and Manufactures, London: John Murray 1846.

BAGiŃski H., Wojsko Polskie na Wschodzie 1914-1920, Warszawa: Główna Księgarnia Wojskowa 1921.

Ben-CanaAn D., Grüner F., ProdöHl I., Entangled Histories. The Transcultural Past of Northeast China, New York: Springer 2014.

BERo E.J., Emigracja polska w stosunku do ogólnej emigracji, Nowy Jork: Nakładem Związku Socjalistów Polskich 1920.

BerżyŃSKi M., Sworakowski W.S., Pięć lat pracy dla Polonii zagranicznej, Warszawa: Rada Organizacyjna Polaków z Zagranicy 1934.

BiaŁYNiA-ChŁodecki J., Ćwierćwiecze kolonii polskiej w Charbinie na Dalekim Wschodzie, Lwów: Nakładem autora 1923.

Bookwalter J.W., Siberia and Central Asia, London: C.A. Pearson 1900.

BREMNER R., Excursion in the Interior of Russia, vol. 2, London: Henry Colburn 1839.

Brereton W.H., The Truth about Opium, London: W. H. Allen and Company 1882.

BukowczyK J.J., A History of the Polish Americans, New Brunswick: Transaction Publishers 2008.

Bukowicz J., Górski T., Marianie 1673-1973, Rzym: Marianorum Immaculatae Conceptionis 1975 .

Bureau of Foreign Commerce, Commercial Relations of the United States with Foreign Countries during the Year 1908, vol. 2, Washington: Department of State 1909.

Cabanowski M., Tajemnice Mandżurii. Polacy w Harbinie, Warszawa: Muzeum Niepodległości 1993.

CAI Y., State and Laid-off Workers in Reform China: The Silence and Collective Action of the Retrenched, London: Routledge 2006.

CARTER J.H., Creating a Chinese Harbin. Nationalism in an International City, Ithaca: Cornell University Press 2002. 
Chang Y., The Economic Development and Prospects of Inner Mongolia (Chahar, Suiyuan, and Ningsia), Shanghai: Commercial Press 1933.

Cioli L., Histoire économique depuis l'antiquité jusqu'à nos jours, Paris: Payot 1938.

Clausen S., Thøgersen S., The Making of a Chinese City. History and Historiography in Harbin, Armonk: M. E. Sharpe 1995.

Cordier H., La Chine, Paris: Payot 1921.

Crawford J.M., The Industries of Russia, St. Petersburg: Trenke and Fusnot 1893.

D’Elia P.M., Fonti Ricciane: Documenti Originali Concernenti Matteo Ricci e la Storia delle Prime Relazioni tra l'Europa e la Cina (1579-1615), Roma: Libreria dello Stato 1942-1949.

De Mello Vianna F., The International Geographic Encyclopedia and Atlas, London: Palgrave Macmillan 1979.

Deog K.Y., Kolonia polska w Mandżurii, Kraków: PROMO 2001.

Doleżan W., Mandżurya. Opis kraju i ludzi, Warszawa: Drukarnia A. T. Jezierskiego 1904.

Dotsenko P., The Struggle for a Democracy in Siberia, 1917-1920. Eyewitness Account of a Contemporary, Stanford: Hoover Institution Press 1983.

Economical Bureau of CER, The Chinese Eastern Railway and its Zone, Harbin: Chinese Eastern Railway Company 1923.

Ефимов Г., Очерки по новой и новейшей истории Китая, Москва: Государственное издательство политической литературы 1951.

Ember M., Ember C.R., Skoggard I., Encyclopedia of Diasporas. Immigrant and Refugee Cultures Around the World, New York: Springer 2005.

EPSTEIN M., The Statesman's Year-Book, London: Macmillan and Company 1936.

EPSTEIN M., The Statesman's Year-Book, London: Macmillan and Company 1940.

EPSTEIN M., The Statesman's Year-Book, London: Macmillan and Company 1943.

Felińska E., Revelations of Siberia. By a Banished Lady, London: Colburn and Publishers 1852.

ГАЛЬПЕРИНА А.Л., Очерки новой истории Японии (1640-1917), Москва: Восточная литература 1958.

Gatrell P., Homelands. War, Population and Statehood in Eastern Europe and Russia, 1918-1924, London: Anthem Press 2004.

GiLes H.A., China and the Manchus, Cambridge: Cambridge University Press 1912.

Golec J., Bojda S., Słownik biograficzny ziemi cieszyńskiej, vol. 2, Cieszyn: Nakładem autorów 1995.

Гончаренко О.Г., Русский Харбин, Москва: Вече 2009.

Gothaisches Jahrbuch Für Diplomatie, Verwaltung und Wirtschaft 1928, Gotha: Perthes 1928. Grabowski E., Rozwój zaludnienia w Polsce w zestawieniu z innemi krajami. Według spisu z dnia 30-go września 1921 roku, Warszawa: Polska Składnica Pomocy Szkolnych 1922.

Great Britain Foreign Office, British Foreign Office. Russia Correspondence, 1781-1945, London: Scholarly Resources Inc. 1975.

Гримм Е.Д., Сборник договоров и других документов по истории международных отношений на Дапьнем Востоке (1842-1925), Москва: Издание Института востоковедения им. Н.Н. Нариманова 1927. 
Grochowski K., Polacy na Dalekim Wschodzie, Harbin: Harbin Daily News 1928.

HAN T.T., De Industrialisatie van China, Gravenhage: Martinus Nijhoff 1922.

ХАРБинский С., Что такое Китайская Восточная ж.д. и куда идут её миллионы?,

Санкт-Петербург: Типо-литография "Печатное искусство" 1908.

Hastings A., A World History of Christianity, London: Eerdmans 1999.

Hoerder D., Cultures in Contact. World Migrations in the Second Millennium, Durham:

Duke University Press 2002.

Hornbeck S.K., Contemporary Politics in the Far East, New York: Appleton and Company 1916.

Hoshiro T., Economic History of Manchuria, Seoul: Bank of Chosen 1921.

Hosie A., Manchuria: Its People, Resources and Recent History, Boston: J.B. Millet 1910.

Hussey H., Manchukuo in Relation to World Peace. Things Not Told in the Report to the

Commission of Enquiry, Geneva: Anti-opium Information Bureau 1932.

IŁowIECKI M., Dzieje nauki polskiej, Warszawa: Wydawnictwo Interpress 1981.

IsETT C.M., State, Peasant and Merchant in Qing Manchuria, 1644-1862, Stanford: Stanford

University Press 2007.

JANIK M., Dzieje Polaków na Syberii, Kraków: Krakowska Spółka Wydawnicza 1928.

KAJDAŃski E., Długi cień wielkiego muru. Jak Polacy odkrywali Chiny, Warszawa: Oficyna Naukowa 2005.

KAJDAŃSKi E., Fort Grochowski, Olsztyn: Wydawnictwo Pojezierze 1982.

KAJDAŃSKi E., Korytarz. Burzliwe dzieje Kolei Wschodniochińskiej 1898-1998, Warszawa:

Książka i Wiedza 2000.

KaJdański E., Polacy na Dalekim Wschodzie. Inżynier Kazimierz Grochowski, Czyngis-chan i złoto barona Ungerna, Warszawa: Książka i Wiedza 2014.

KAJDAŃSKi E., Wspomnienia z mojej Atlantydy, Kraków: Wydawnictwo Literackie 2013.

KaŁuski M., Polacy w Chinach, Warszawa: Instytut Wydawniczy Pax 2001.

KiziLov M., The Sons of Scripture. The Karaites in Poland and Lithuania in the Twentieth Century, Warsaw: De Gruyter 2015.

КлючНиков Ю.В., САБАКИН А., Международная политика новейшего времени в договорах, нотах и декларациях. Часть 1: От Французской революции до империалистической войны, Москва: Литиздат НКИД 1925.

Kolarz W., Russia and Her Colonies, London: G. Philip and Son 1952.

Kolarz W., The Peoples of the Soviet Far East, New York: Frederick A. Praeger 1954.

KolodzIEJ E., Organizacje polskie w Mandżurii w latach 1917-1920, in: A. KoSESKI (ed.), Polonia w walce o niepodległość Rzeczypospolitej 1914-1921, Pułtusk: Wyższa Szkoła Humanistyczna w Pułtusku 1999, s. 195-205.

Komorowski W., Daleki Wschód w międzynarodowej polityce gospodarczej, Warszawa: Wydawnictwo Kasy im. Mianowskiego 1931.

КонаРев Н.С., Железнодорожный транспорт: Энциклопедия, Москва: Большая Российская энциклопедия 1994.

KorfF S.A., Russia in the Far East, Washington: American Society for International Law 1921. KrAHMER G., Syberya i znaczenie wielkiej kolei syberyjskiej, Warszawa: Redakcja i Administracja Biblioteki Dzieł Wyborowych 1898. 
KuCZyŃSKi A., Syberia. Czterysta lat polskiej diaspory, Wrocław: Atlas 1998.

KuCZYŃsKi A., Syberyjskie szlaki, Wrocław: Ossolineum 1972.

Kuromiya H., PepŁoński A., Między Warszawą a Tokio. Polsko-japońska współpraca wywiadowcza 1904-1944, Toruń: Adam Marszałek 2009.

La Motte E.N., The Opium Monopoly, New York: The Macmillan Company 1920.

Lerski J.J., WróBel P., KozicKi R.J., Historical Dictionary of Poland, 966-1945, Westport: Greenwood Press 1996.

Liberman Y., My China. Jewish Life in the Orient, 1900-1950, Jerusalem: Gefen Publishing House 1998.

Livingston J., Moore J., Oldfather F., Imperial Japan, 1800-1945, New York: Pantheon Books 1973.

Łossowski P., Historia dyplomacji polskiej, vol. 4: 1918-1939, Warszawa: Wydawnictwo Naukowe PWN 1995.

Łoza S., Czy wiesz kto to jest?, Warszawa: Wydawnictwo Głównej Księgarni Wojskowej 1938.

MacMurray J.V.A., Treaties and Agreements with and Concerning China 1894-1919, vol. 1, Washington: Oxford University Press 1921.

Majdowski A., Kościół katolicki w cesarstwie rosyjskim. Syberia, Daleki Wschód, Azja Środkowa, Warszawa: Neriton 2001.

Masson D., The Collected Writing of Thomas de Quincey, vol. 14, London: A.C. Black 1897. Matheson D., What is Opium Trade?, Edinburgh: Thomas Constable and Company 1857. Matsusaka Y.T., The Making of Japanese Manchuria, 1904-1932, Cambridge: Harvard University Press 2001.

MAYERS W.F., Treaties between the Empire of China and foreign powers together with regulations for the conduct of foreign trade, conventions, agreements, regulations, etc., Shanghai: North China Herald 1906.

Мелихов Г.В., Маньчжурия далекая и близкая, Москва: Главная редакция восточной литературы издательства “Наука" 1991.

Melvill J.C., Opium Trade: A Copy of all Papers and Despatches at the India House, on the Subject of Hostilities between the Chinese and British Subjects engaged in the Opium Trade, from 1830 to 1833, both Years Inclusive, London: House of Commons 1840.

Meyer M., In Manchuria: A Village Called Wasteland and the Transformation of Rural China, New York: Bloomsbury Publishing 2015.

Michell T., Russian Pictures Drawn with Pen and Pencil, London: Religious Tract Society 1889.

Mikhoilov I.A., North Manchuria and the Chinese Eastern Railway, Harbin: Chinese Eastern Railway Company 1924.

Montague Bell H.T., Woodhead H.G.W., The China Year Book 1919, London: North China Daily News 1919.

Moustafine M., Secrets and Spies. The Harbin Files, London: Vintage 2002.

Mroczkowska M., Szczepaniak K., Stosunki dyplomatyczne Polski. Informator, vol. 3: Azja, Zakaukazie, Australia i Oceania 1918-2009, Warszawa: Wydawnictwo Askon 2010. 
NeJa J., Harbin jako przestrzeń życia i działalności Polonii mandżurskiej, in: A. FurIER (ed.), Polskie ślady na Dalekim Wschodzie. Polacy w Harbinie, Szczecin: Książnica Pomorska 2008, pp. 50-76.

Ogata S.N., Defiance in Manchuria. The Making of Japanese Foreign Policy, 1931-1932, Westport: Greenwood Press 1984.

PArker E.H., Chinese Account of the Opium War, Shanghai: Kelly and Walsh 1888.

PatrikeefF F., Russian Politics in Exile. The Northeast Asian Balance of Power, 1924-1931, Oxford: Palgrave Macmillan 2002.

PatrikeefF F., Shukman H., Railways and the Russo-Japanese War. Transporting War, New York: Routledge 2007.

Петров В.П., Город на Сунгари, Вашингтон: Русско-американского исторического общества 1984.

Piotrowski R., My Escape from Siberia, London: Routledge, Warne and Routledge 1863. Polska służba zagraniczna po 1 września 1939 r., Londyn: Wydawnictwo Stowarzyszenia Pracowników Polskiej Służby Zagranicznej 1954.

Prange G.W., Goldstein D.M., Dillon K.V., December 7, 1941. The Day the Japanese Attacked Pearl Harbor, New York: McGraw-Hill 1988.

Putnam Weale B.L., The Coming Struggle in Eastern Asia, London: Macmillan and Company 1908.

Putnam Weale B.L., The Truth about China and Japan, New York: Dodd, Mead and Company 1919.

PuYi Aisin Gioro, From emperor to citizen. The autobiography of Aisin-Gioro Pu Yi, vol. 2, Peking: Foreign Languages Press 1964.

Quested R.K.I., “Matey” Imperialists: the Tsarist Russians in Manchuria 1895-1917, Hong Kong: University of Hong Kong Press 1982.

Reyman E.J., Encyklopedia nauk politycznych, vol. 3, Warszawa: Biblioteka Polska 1938. Ristaino M.R., Port of Last Resort. The Diaspora Communities of Shanghai, Stanford: Stanford University Press 2001.

Rocznik Służby Zagranicznej RP, Warszawa: Ministerstwo Spraw Zagranicznych 1935.

Романов Б.А., Очерки дипломатической истории русско-японской войны, Москва: Издательство Академии Наук СССР 1955.

Scott-Keltie J., Howarth O.J.R., History of Geography, London: Watts and Company 1913. Scott-Keltie J., The Statesman's Year-Book, London: Macmillan and Company 1885. Scott-Keltie J., The Statesman's Year-Book, London: Macmillan and Company 1905. Scott-Keltie J., The Statesman's Year-Book, London: Macmillan and Company 1908. SEE C.S., The Foreign Trade of China, New York: Columbia University Press 1919.

Sieroszewski W., Dwanaście lat w kraju Jakutów, Warszawa: Nakładem drukarni Karpińskiego 1900.

SKóRA W., Organizacja i pierwszy okres działalności polskich konsulatów w Harbinie i Władywostoku w latach 1920-1924, in: A. FurIer (ed.), Polskie ślady na Dalekim Wschodzie. Polacy w Harbinie, Szczecin: Książnica Pomorska 2008, pp. 75-100.

SKóRA W., Placówki MSZ Drugiej Rzeczypospolitej w Harbinie w latach 1920-1941 na tle dziejów Chin i Mandżurii (Mandżukuo). Szkic do problemu, in: A. Teterycz-Puzio 
(ed.), Na szlakach dwóch światów. Studia ofiarowane Profesorowi Jerzemu Hauzińskiemu w 45-lecie pracy naukowej i dydaktycznej, Słupsk: Wydawnictwo Akademii Pomorskiej 2016, pp. 677-717.

SkóRA W., Służba konsularna Drugiej Rzeczypospolitej. Organizacja, kadry i działalność, Toruń: Adam Marszałek 2006.

Smith A.H., The Uplift of China, New York: Missionary Education Movement of the United States and Canada 1907.

Stanford E., Atlas of the Chinese Empire Containing Separate Maps of the Eighteen

Provinces of China Proper and the Four Great Dependencies, London: Morgan and Scott 1908.

StePHAn J.J., The Russian Far East. A History, Stanford: Stanford University Press 1994. Symonolewicz K., Miraże Mandżurskie, Warszawa: Gebethner i Wolff 1932.

Тацвот F.A., The Railway Conquest of the World, Philadelphia: J.B. Lippincott Company 1911.

ТАскина Е., Неизвестный Харбин, Москва: Прометей 1994.

The International Anti-Opium Association in Peking, The War Against Opium, Tientsin: Tientsin Press 1922.

TheIss W., Dzieci syberyjskie. Dzieje polskich dzieci repatriowanych z Syberii i Mandżurii w latach 1919-1923, Warszawa: Wydawnictwo Uniwersytetu Warszawskiego 1992.

Thomas W.I., Znaniecki F., The Polish Peasant in Europe and America, vol. 1, New York: Alfred A. Knopf 1927.

ToKARSKi J., Przez Syberię, Mandżurię i Japonię do brzegów Oceanu Spokojnego, Lwów: Macierz Polska 1911.

Tong H.K., Facts about the Chinese Eastern Railway Situation, Harbin: Committee for Public Enlightenment of Northeastern Provinces 1929.

TYcZKa J., Na wschodzie i na zachodzie, Warszawa: Verbinum 2003.

United States Strategic Bombing Survey, Coals and Metals in Japan's War Economy, Washington: Basic Materials Division 1947.

Urbansky S., Kolonialer Wettstreit. Russland, China, Japan und die Ostchinesische Eisenbahn, Frankfurt am Main: Campus Verlag 2008.

Victorr L., ZatsePine V., Harbin to Hanoi. The Colonial Built Environment in Asia, 18401940, Hong Kong: Hong Kong University Press 2013.

VINING L.E., Held by the Bolsheviks. The Diary of a British Officer in Russia, 1919-1920, London: Saint Catherine Press 1924.

Wagel S.R., Finance in China, Shanghai; Garland Publishing 1914.

White J.A., Diplomacy of the Russo-Japanese War, Princeton: Princeton University Press 1964.

WierzbiaŃski B., Polacy w świecie, Londyn: Wydawnictwo Światowego Związku Polaków z Zagranicy 1946.

WierZBIAŃSKi B., Polonia zagraniczna w latach 1939-1946, Londyn: Wydawnictwo Światowego Związku Polaków z Zagranicy 1946.

WiLson W., Selected Addresses and Public Papers, New York: Harper 1918. 
Winiarz A., Główne kierunki i formy aktywności Polaków w Mandżurii w latach 18971949, in: A. FurIER (ed.), Polskie ślady na Dalekim Wschodzie. Polacy w Harbinie, Szczecin: Książnica Pomorska 2008, pp. 27-49.

Witte S.Y., The Memoirs of Count Witte, translated by A. Yarmolinsky, Garden City: William Heinemann 1921.

WolfF D., To the Harbin Station: The Liberal Alternative in Russian Manchuria, 1898-1914, Stanford: Stanford University Press 1999.

Woodhead H.G.W., Montague Bell H.T., The China Year Book 1921, Tientsin: North China Daily News 1922.

YAKHONTOFF V.A., Eyes on Japan, New York: Coward-McCann 1936.

Young C.W., Japanese Jurisdiction in the South Manchuria Railway Areas, Baltimore: Johns Hopkins Press 1931.

\section{Periodicals}

BAKICH O., Émigré Identity: The Case of Harbin, „The South Atlantic Quarterly”, vol. 99, no. 1, Winter 2000, pp. 51-73.

BAKICh O., Russian City in China: Harbin before 1917, „Canadian Slavonic Papers”, vol. 28, no. 2, March 1985, pp. 129-148.

„Biuletyn Polskiej Izby Handlowej w Harbinie”, no. 5, 1932, p. 3.

„Boston Post”, April 27, 1903, p. 4.

Cloud F.D., Why America is so interested in Manchuria, „New York Times”, March 27, 1910, pp. 43-44.

„Daleki Wschód”, no. 5, 1934, p. 14.

„Daleki Wschód”, no. 7, 1934, p. 1.

„Echo z Dalekiego Wschodu”, no. 3, 1934, p. 17.

„Echo z Dalekiego Wschodu”, no. 3, 1939, pp. 17-18.

Extra Ships are Chartered for Run, „The Daily Colonist”, March 5, 1915, p. 10.

FrYCZ K., Wyrok Sądu Obywatelskiego, „Listy Polskie z Dalekiego Wschodu”, no. 7, July 7, 1918, pp. 8-13.

„Gazeta Grudziądzka”, no. 126, January 30, 1904, p. 2.

„Gazeta Grudziądzka”, no. 37, March 26, 1905, p. 4.

GieYsZTOR J., Kolej Syberyjska, „Kraj”, no. 18, May 14, 1897, pp. 2-6.

Grochowski A., Jeszcze o Polonii Mandżurskiej, „Nasza Rodzina”, no. 11(482), November 1984, pp. 32-35.

Harbin, the Wonderful New Russian City in Manchuria, „Galveston Daily News”, February 27, 1904, p. 8.

Historia Parafii Polsko Katolickiej w Charbinie (Chiny), „Pamiętnik Charbiński”, vol. 1, 1923, pp. 22-23.

„Inżynier Kolejowy”, no. 8-9, 1926, pp. 239

Kaluski M., Polacy w rosyjskiej Mandżurii, „Studia Polonijne”, vol. 22, 2001, pp. 109-149.

KIL J., GraczyK K., Kolonia polska w Mandżurii - analiza historycznoprawna, „Z Dziejów Prawa", vol. 6(14), 2013, pp. 105-126. 
„Kosmos”, vol. 25, 1900, p. 690.

„Laurel Daily Leader”, July 25, 1929, pp. 4-5.

Le soja: Nationalisation de cette industrie au Mandchoukouo, „Revue Internationale des

Produits Coloniaux et du Matérial Colonial", vol. 14, no. 164-166, 1939, pp. 259-262. „Listy Harbińskie”, no. 5, 1932, p. 2.

„Listy Harbińskie. Numer Noworoczny”, no. 1, January 1, 1932, p. 8.

„London Standard”, January 4, 1904, p. 5.

Manchuria. Place of Possibilities for Japan, „Boston Daily Globe”, March 11, 1905, pp. 4-5. Manchurian Trouble, „Boston Daily Globe”, April 24, 1903, p. 22.

Milling in Manchuria, „American Miller and Processor”, no. 1-6, vol. 38, 1910, p. 309.

Milling in Manchuria, „The Northwestern Miller”, no. 76, 1908, p. 155.

Neja J., Polacy w Mandżurii, „Biuletyn Instytutu Pamięci Narodowej”, no. 3, 2002, pp. 34-41.

NernHeJM S., Polonia harbińska (zarys historyczny), „Daleki Wschód”, no. 7(57), 1934, p. 1. „New York Times”, July 17, 1910, p. 40.

„New York Times”, March 9, 1910, pp. 8-9.

Odznaczenie chińskie dla P. Patka, „Gazeta Lwowska”, no. 132, June 12, 1928, p. 1.

„Pamiętnik Charbiński”, vol. 1, 1923, pp. 23-24.

PelC W., Mandżurska Polonia, „Nasza Rodzina”, no. 2(473), February 1984, pp. 30-35.

„Polish Fortnightly Review”, vol. 25, December 1941, pp. 7-8.

„Praca. Pismo Postępowe Demoktratyczne”, no. 8, May 12, 1918, p. 10.

„Przegląd Krytyczny”, no. 8, 31 August 1877, p. 286.

РАдлов В.В., Отзыв к Э. К. Пекарский. Словарь якутского языка, „Живая Старина”, vol. 4, 1907, pp. 63-65.

Rozwój stosunków polsko-chińskich (1917-1936), „Polityka Narodów”, vol. X, no. 3, 1937, p. 148.

„San Antonio Express”, September 20, 1931, p. 2.

SkóRA W., Sytuacja materialna Polonii mandżurskiej w 1929 roku (w świetle raportu konsula RP Konstantego Symonolewicza), „Przegląd Orientalistyczny”, no. 3-4, 2010, pp. 125-140.

Stowarzyszenia polskie w Charbinie, „Pamiętnik Charbiński”, vol. 1, 1923, p. 18.

SzYMAŃsKi J., Opieka duszpasterska nad Polakami w Harbinie, „Studia Polonijne”, vol. 38, 2017, pp. 37-59.

„Światowit”. Rocznik poświęcony archeologii i badaniom pierwotnej kultury polskiej i słowiańskiej, vol. 12-14, 1926, pp. 1-5.

Three Powers to Forcibly Protest, „Boston Daily Globe”, April 25, 1903, p. 8.

„Tygodnik Polski”, no. 15, April 9, 1939, p. 7.

„Вестник Европы”, vol. 233, 1905, pp. 233-234.

Winiarz A., Działalność Polskiego Komitetu Opiekuńczego w Harbinie (1942-1945), „Rocznik Polonijny”, 1984-1985, pp. 195-206.

Wojas B.Z., Dzieje Polonii Charbińskiej, ,Zeszyty Historyczne”, vol. 30(250), 1974, p. 13. Wybory Delegata na III Zjazd Polaków z Zagranicy, „Tygodnik Polski”, no. 23, June 4, 1939, p. 3. 


\section{POLSKIE OSADNICTWO W MANDŻURII (1898-1950) KRÓTKI RYS HISTORYCZNY}

\section{Streszczenie}

Pod koniec XIX wieku rozmaite względy geopolityczne, militarne, polityczne i ekonomiczne skłoniły władze carskiej Rosji do prowadzenia polityki masowej kolonizacji Dalekiego Wschodu. Proces ten doprowadził do pojawienia się licznych słowiańskich enklaw w północno-wschodnich Chinach poczynając od końca 1890 roku. W konsekwencji północna Mandżuria stała się ostatnim ważnym miejscem spotkań europejskich osadników i azjatyckich mieszkańców pogranicza obejmującego Imperium Rosyjskie i Cesarstwo Chin. Europejskie osadnictwo w Mandżurii odcisnęło głębokie piętno na zmieniającym się krajobrazie tego regionu w najbliższym półwieczu.

Na początku XX wieku wielu Polaków wyemigrowało na Daleki Wschód w poszukiwaniu lepszych warunków życia. Udało im się znaleźć pracę przy budowie Kolei Wschodniochińskiej i obsłudze nowej linii kolejowej. Inni znaleźli zatrudnienie jako lekarze, inżynierowie, bankierzy i prawnicy. Tym sposobem, w przeciwieństwie do innych środowisk polonijnych, grupa ta w dużej mierze składała się z zamożnych i wykształconych osób.

Słowa kluczowe: diaspora polska; Mandżuria; polskie osadnictwo; Chiny Północno-Wschodnie

\section{POLISH SETTLEMENT IN MANCHURIA (1898-1950) A BRIEF HISTORICAL SURVEY}

\section{Sum mary}

During the late nineteenth century, geopolitical, military, political as well as economic considerations combined to induce the Tsarist government to pursue a policy of mass colonization of the Far East. This process led to the appearance of numerous Slavic enclaves in Northeastern China from the late 1890s onwards. As a consequence, northern Manchuria became the final major meeting point between European settlers and Asian inhabitants of the borderland encompassing Tsarist Russia as well as Imperial China. The European settlement in Manchuria was to leave profound imprints on the region's changing landscape for the next half-century.

At the beginning of the twentieth century, numerous Poles migrated to the Far East in pursuit of better economic conditions. They found work building the Chinese Eastern Railway and remained behind to help operate the line. Others were employed as physicians, engineers, bankers and lawyers. In this way, unlike other Polish diaspora communities, this grup largely comprised wealthy and educated individuals.

Key words: Polish diaspora; Manchuria; Polish settlement; Northeastern China 